\title{
Polycyclic Aromatic Hydrocarbons (PAHs) in Main urban area Soils of Changchun, Northeast China: Status, Sources, and Potential Toxic Risk Assessment
}

\author{
Wei Zhao, Jing Li, Jilong Lu*, Tian Lan, Libin Zang, Jinke Guo, Tong Li \\ College of Geo-Exploration Science and Technology, Jilin University, Changchun 130026, China
}

Received: 11 August 2021

Accepted: 7 December 2021

\begin{abstract}
This study comprehensively investigated the occurrence, sources, and potential toxicity risks of 16 PAHs in main urban area surface soils of Changchun, northeast China. The 16 total PAHs $\left(\Sigma_{16}\right.$ PAHs $)$ concentrations in surface soils decreased significantly along the commercial traffic district, industrial zone, residential zone, park zone, and outskirt farmland, ranging from 46.6 to $8870.8 \mathrm{ng} / \mathrm{g}$, with a mean value of $1480.1 \mathrm{ng} / \mathrm{g}$ and 4-ring PAHs were always the dominant constituents in all land used area soils. Based on ArcGIS mapping, higher concentrations of PAHs are mainly concentrated in the northeast region and the central historic district soils of Changchun city. Mixed pyrogenic sources and coal combustion were the dominant sources and contributed approximately $45 \%$ and $30 \%$ of the total soil PAHs, respectively. Toxicity risk assessment based on the toxic equivalent concentrations $\left(\mathrm{BaP}_{\mathrm{eq}}\right)$ of soil PAHs indicated the potential toxicity risks detected in this study were relatively moderate compared with other global cities, while some special attention still should be paid to hotspots with high PAHs concentrations surrounding the commercial traffic area and industrial zone in the northeast pattern of Changchun city. This study could be potentially useful for local governments targeted to control toxicity exposure, promote actions to alleviate PAHs contamination.
\end{abstract}

Keywords: PAHs, urban soils, Changchun, principal component analysis, $\mathrm{BaP}_{\text {eq }}$

\section{Introduction}

Polycyclic aromatic hydrocarbons (PAHs) are a group of ubiquitous persistent organic contaminants consisting of two or more fused aromatic rings [1]. They have attracted considerable research attention

*e-mail: luj1@jlu.edu.cn due to their environmental persistence and significant health risk as carcinogens and mutagens [2-4]. Among hundreds of different PAHs, 16 PAH compounds have been listed as the priority pollutants by the United States Environment Protection Agency (US EPA) and seven of these priority pollutants have been classified as the probable human carcinogens by the International Agency for Research on Cancer (IARC) [5]. Based on their formation process, PAHs mainly originated 
from pyrogenic, petrogenic, and biogenic sources, and pyrogenic PAHs results from incomplete combustion of organic carbon such as vehicle emission have been reported as the most contributors [6].

In recent decades, the unprecedented rapid development of urbanization and industrialization in China has created giant economic growth, while simultaneously resulting in significant levels of urban environmental pollution, especially the continuous and increased emissions of potentially toxic PAHs [3]. It is reported that motor vehicles can contribute to approximately $36 \%$ of annual total PAH emissions [7]. Soil is the most important sink for PAHs in the terrestrial system and approximately $90 \%$ of the total PAHs retain in surface soil [8]. PAHs derived from anthropogenic activities can enter urban soils via dry or wet deposition after transporting in the atmosphere over long distances [9]. Further, urban soil PAHs can be also the source of atmospheric and water PAHs through volatilization and surface runoff, thereby increasing the urban ecological environment security and PAHs exposure to urban residents [10]. They can accumulate into human bodies through dermal contact and/or ingestion of contaminated food and pose a threat to inhabitants' health [11-12]. Therefore, understanding the occurrence, distribution and negative effects of PAHs in urban surface soil is a critical issue for ensuring urban public health.

Changchun, a major industrial center in northeastern China, is one of the most industrialized and economically significant cities in China and its environment has been subjected to heavy anthropogenic influences with rapid urbanization and industrialization. It has many industry segments such as the automotive industries, coal-fired power plants, metallurgy, iron and steel mills, construction material manufacturers, and chemical plants [13]. As a high population density city, the total population of Changchun had reached 9.06 million in 2020, including 5.81 million in the main municipal area, accounting for $64.08 \%$ of its total population [14]. The local energy structure is dominated by fossil fuels (coal, natural gas, and petroleum) and biomass combustion, which total consumed 17.5 million tons of standard coal energy (SCE) annually and resulted in large amounts of PAHs emitting into the environment [15]. Previous studies on PAHs in Changchun have mainly focused on atmospheric particulate matters [16-18]. Research showed that the total concentrations of 16 PAHs in the atmospheric particulate matter were $1.57 \mathrm{ng} / \mathrm{m}^{3}$ and $1.10 \mathrm{ng} / \mathrm{m}^{3}$ during the heating period and non-heating period [16]. However, limited studies have been investigated on PAHs pollution in different urban land used pattern soils of Changchun. Therefore, the objectives of this study are to (1) investigate the pollution levels and spatial distribution of PAHs in urban soils from different land used areas of Changchun; (2) identify possible sources of PAHs in urban soils from Changchun; and (3) assess toxic ecological risk of PAHs to residents.

\section{Material and Methods}

\author{
Study Area and Soil Sampling
}

Changchun $\quad\left(124^{\circ} 18^{\prime} \sim 127^{\circ} 02^{\prime} \mathrm{E}, 43^{\circ} 05^{\prime} \sim 45^{\circ} 15^{\prime} \mathrm{N}\right)$, with a total city area of $20593 \mathrm{~km}^{2}$ and the district area of $543 \mathrm{~km}^{2}$ [15], is the capital city of Jilin province, located in the hinterland of Songliao plain in northeast China. It has a north temperate zone continental climate, with an annual average temperature of $6.7^{\circ} \mathrm{C}$, characterized by long and cold winters, while warm and short summers. The annual frost-free period lasts about 134-140 days and the heating period can last from October to the following March [19], which may further influence the levels of PAHs contamination in urban surface soil as the temperature is a very important factor in determining the degradation of soil PAHs [20]. The soil types are mainly dominated by black soil, dark brown soil, and meadow soil.

48 surface soil samples and 4 background samples were collected from the main urban district and suburban cultivated land of Changchun city in October 2019 (Fig. 1). The main urban district samples were divided into park zone (PZ) samples, industrial zone (IZ) samples, residential zone (RZ) samples, commercial traffic area (CT) samples, and outskirt farmland (OF) samples according to their different land used pattern locations. Each sampling site was set in a $10 \mathrm{~m} \times 10 \mathrm{~m}$ grid, and five surface subsamples $(0-20 \mathrm{~cm})$ according to the diagonal rule were taken to mixed as one composite sample. All soil samples were freeze-dried at $-50^{\circ} \mathrm{C}$ for $24 \mathrm{~h}$ and sieved to 80 mesh after removing stones, leaves and other impurities, then sealed in polyethylene bags and stored at $-4^{\circ} \mathrm{C}$ until further analysis of total organic carbon (TOC) and PAHs.

\section{Reagents and Materials}

A composite standard solution of sixteen US EPA priority-listed PAHs was purchased from Tan-Mo Technology Co.; Ltd (Beijing, China), the names and abbreviations of PAHs are listed in Table 1. A deuterated PAHs mixture standard solution containing naphthalene-d8, acenaphthene-d10, phenanthrene-d10, chrysene-d12, and perylene-d12 in dichloromethane solvent was used as the internal standard chemicals for quality monitoring during detection. 2-fluorophenyl and p-terphenyl-d14 mixed in n-hexane and acetone (1:1) solvent were used as the surrogate standards for quality monitoring during the pretreatment process. Dichloromethane (DCM), n-hexane, acetone solvents at chromatographic grade, and anhydrous ethanol at analytical grade were purchased from Haodi Chemical reagent Co.; Ltd (Jilin, China). Granular diatomite (20-40 mesh) and quartz sand were purified at $400^{\circ} \mathrm{C}$ for $4 \mathrm{~h}$, then kept in a desiccator using as desiccants and filters. 


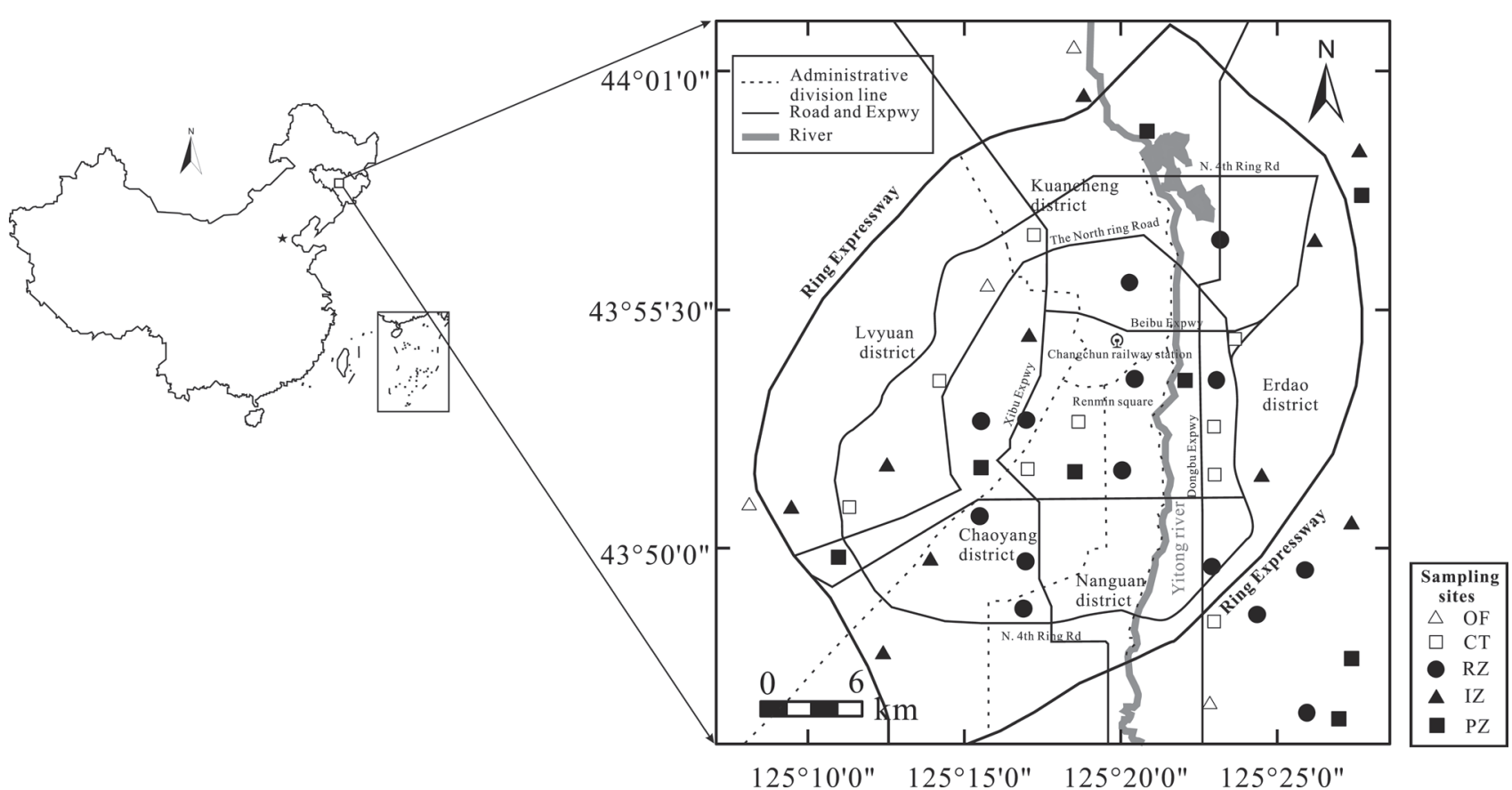

Fig. 1. Map of the soil sampling sites in the main urban district of Changchun, NE China (sampling sites including: park zone (PZ), industrial zone (IZ), residential zone (RZ), commercial traffic area (CT), and outskirt farmland (OF)).

Table 1. Retention time and precision for the determination of 16 PAHs by GC-MS.

\begin{tabular}{|c|c|c|c|c|c|c|}
\hline PAH congeners & Abbreviations & Rings & $\mathrm{RT}^{\mathrm{a}}(\mathrm{min})$ & $\mathrm{MDLs}^{\mathrm{b}}(\mathrm{ng} / \mathrm{g})$ & $\mathrm{R}^{\mathrm{c}}$ & $\mathrm{DF}^{\mathrm{d}}$ \\
\hline Naphthalene & Nap & 2 & 7.118 & 1.6 & 0.9964 & $90 \%$ \\
\hline Acenaphthylene & Acy & 2 & 9.972 & 0.8 & 0.9952 & $77 \%$ \\
\hline Acenaphthene & Ace & 2 & 10.430 & 0.5 & 0.9961 & $85 \%$ \\
\hline Fluorene & Flu & 2 & 12.111 & 0.8 & 0.9958 & $88 \%$ \\
\hline Phenanthrene & Phe & 3 & 15.626 & 2.1 & 0.9912 & $100 \%$ \\
\hline Anthracene & Ant & 3 & 15.780 & 1.8 & 0.9968 & $98 \%$ \\
\hline Fluoranthene & Fla & 3 & 19.680 & 3.6 & 0.9958 & $90 \%$ \\
\hline Pyrene & Pyr & 4 & 20.601 & 3.6 & 0.9963 & $96 \%$ \\
\hline Benzo[a]anthracene & BaA & 4 & 27.043 & 2.8 & 0.9960 & $100 \%$ \\
\hline Chrysene & Chr & 4 & 27.245 & 3.1 & 0.9957 & $100 \%$ \\
\hline Benzo[b]fluoranthene & BbF & 4 & 32.763 & 6.5 & 0.9956 & $88 \%$ \\
\hline Benzo[k]fluoranthene & BkF & 4 & 32.770 & 2.8 & 0.9963 & $98 \%$ \\
\hline Benzo[a]pyrene & BaP & 5 & 34.140 & 1.8 & 0.9966 & $100 \%$ \\
\hline Indeno[1,2,3-cd] pyrene & IcdP & 5 & 40.910 & 3.4 & 0.9966 & $81 \%$ \\
\hline Dibenz[a,h]anthracene & DB(a,h)A & 5 & 41.160 & 2.4 & 0.9964 & $58 \%$ \\
\hline Benzo[ghi]perylene & BghiP & 6 & 42.870 & 2.5 & 0.9976 & $88 \%$ \\
\hline
\end{tabular}

${ }^{\mathrm{a}} \mathrm{RT}$ : Retention time; ${ }^{\mathrm{b}}$ MDLs: Method detection limits, they were experimentally calculated as $3.143 \sigma$, where $\sigma$ is the standard deviation of the response of 7 parallel analyses for the blank sample (quartz sand) containing the standard solution of $20 \mathrm{ng} / \mathrm{g}$; ${ }^{\mathrm{c}} \mathrm{R}$ : Correlation coefficient of calibration curve; ${ }^{\mathrm{d}} \mathrm{DF}$ : detection frequency 


\section{Extraction and Analysis of PAHs}

Exactly $15.0 \mathrm{~g}$ freeze-dried soil samples spiked with surrogate standard mixture were extracted with an accelerated solvent extractor (APLE-2000, Jitian Instrument Co., Ltd, Beijing, China) using a mixture of DCM-hexane $(1: 1, \mathrm{v} / \mathrm{v})$. Soil samples were extracted 2 times under $100^{\circ} \mathrm{C}, 10 \mathrm{MPa}$. The static time was $5 \mathrm{~min}$, the flush volume was $60 \%$, and the purge time was the $90 \mathrm{~s}$. The final extracts were concentrated to approximately $2 \mathrm{ml}$ with a vacuum rotary evaporator (Yarong Instrument Co., Ltd, Shanghai, China) with a $50^{\circ} \mathrm{C}$ water bath and $60 \mathrm{RPM}$ of spin rate, then cleaned up using a Florisil cartridges column $(1000 \mathrm{mg}, 6 \mathrm{ml})$ equipped on a solid phase setup. Before purification, $5 \mathrm{~mL} \mathrm{DCM}$ and $10 \mathrm{~mL}$-hexne were added to activate the magnesium silicate column and the fraction was discarded. The extracts were then eluted with $10 \mathrm{~mL}$ $\mathrm{DCM} / \mathrm{n}$-hexane $(2: 8, \mathrm{v} / \mathrm{v})$ through the column. All eluents were collected and concentrated to $1.0 \mathrm{~mL}$, then transferred to a clean vial. Then internal standards were added to the bottle before instrumental analysis.

Sixteen US EPA priority-listed PAHs were detected on Clarus 580/680 gas chromatograph -SQ8 mass spectrometry (ClarusSQ8 GC-MS, PerkinElmer, USA), equipped with a DB-5 elastic quartz capillary column (30 $\mathrm{m} \times 0.25 \mathrm{~mm} \times 0.25 \mu \mathrm{m}$ ), using ultrapure helium ( $>99.999 \%$ pure) as the carrier gas. The sample extracts (each $1.0 \mu \mathrm{L}$ ) were injected in the splitless mode. The oven temperature program was set as follows: held at $80^{\circ} \mathrm{C}$ for $2 \mathrm{~min}$, increased to $180^{\circ} \mathrm{C}$ at a heating rate of $20^{\circ} \mathrm{C} / \mathrm{min}$, holding for $5 \mathrm{~min}$, then raised to $240^{\circ} \mathrm{C}$ with $5^{\circ} \mathrm{C} / \mathrm{min}$, holding for $5 \mathrm{~min}$, finally from $240^{\circ} \mathrm{C}$ to $290^{\circ} \mathrm{C}$ at $10^{\circ} \mathrm{C} / \mathrm{min}$, and holding for $8 \mathrm{~min}$. The MS was operated in electron impact ionization mode with electron energy of $70 \mathrm{eV}$. The inlet and transfer line temperature were both $280^{\circ} \mathrm{C}$ and the iron source temperature was $230^{\circ} \mathrm{C}$. A composite standard of 16 PAHs solution was analyzed by GC-MS in MS scan mode to record the retention time of each target compound for the qualitative analysis (Table 1). Quantification of each PAH compound based on the selective ion monitoring (SIM) mode was carried out using internal standard calibrations with peak area.

\section{Quality Assurance and Quality Control}

Strict quality control procedures were applied to monitor the validity of data. The calculated calibration curves (gradient of $0,0.5,1,5,10 \mu \mathrm{g} / \mathrm{mL}$ concentration standard solutions containing individual PAHs) showed high-level linearity for all target analytes. The method detection limits (MDLs) for individual PAHs ranged from 0.5 to $6.5 \mathrm{ng} / \mathrm{g}$, as described in detail in Table 1 . One laboratory blank sample (equivalent quartz sand instead of soil sample) and one duplicate sample were run with every batch of 12 samples. The concentration of PAHs detected in the blank samples was negligible, and the relative standard deviation of PAH in random duplicate was less than $15 \%$. In addition, the surrogate standards and the deuterated PAHs mixture standard were added to all soil samples to monitor the procedural performance. Mean recovery of all samples for 2-fluorophenyl and p-terphenyl-d14 was $62 \%$ and $128 \%$, respectively and the recoveries of five deuterated internal standards ranged from $89 \%$ to $109 \%$.

\section{Determination of Soil $\mathrm{pH}$ and TOC}

Soil $\mathrm{pH}$ was determined with a $\mathrm{pH}$ meter (PB-21, Sartorius, Germany) in a 1:2.5 suspension $\mathrm{H}_{2} \mathrm{O}$. Soil total organic carbon (TOC) was determined through the potassium dichromate volumetric method, which is a standard method recommended by the Chinese Society of Soil Science [21]. Briefly, soil organic carbon was oxidized into carbon dioxide by quantitative potassium dichromate solution under the condition of oil bath heating, while potassium dichromate $\left(\mathrm{K}_{2} \mathrm{Cr}_{2} \mathrm{O}_{7}\right)$ is reduced to $\mathrm{Cr}^{3+}$. The remaining $\mathrm{K}_{2} \mathrm{Cr}_{2} \mathrm{O}_{7}$ was titrated by $\mathrm{FeSO}_{4}$ and the concentrations of soil TOC can be calculated quantitatively on basis of the change of potassium dichromate before and after oxidation of soil organic carbon.

\section{Data Analyses Method}

Both PAH diagnostic ratios and principal component analysis coupled with multivariate linear regression (PCA-MLR) were chosen in this study to identify the major sources of PAHs in the main urban area soils of Changchun. PCA-MLR is a commonly applied technique to quantitatively appoint the pollution sources of PAHs in the environment as it only needs to roughly understand the composition of pollutant emission sources without the accurate source component data. Principal component analysis (PCA) was used to reduce the dimensionality of receptor data, and extract valuable representative factors information from multivariate. Under utilizing the orthogonal transformation method, several principal components (PCs) can be extracted with different factor loadings which can indicate different pollution sources [22]. Multivariate linear regression (MLR) aims to appoint the relative contribution of each pollution source using ordinary least squares based on the identification of emission sources [23]. It is performed between the PCs and the sum of pollutants, and the standardized regression coefficients were used to calculate the relative contributions of various PAH sources. The model of MLR was as follows:

$$
Z_{P A H S}=\sum_{\mathrm{i}=1}^{n} m_{i} f_{i}+b
$$

Where, $Z_{P A H S}$ is the dependent variable represented by the standardized total 16 PAH concentration values; $n$ is the number of extracted principal components 
(PCs); $m_{i}$ is the standardized regression coefficient; $f_{i}$ is the standardized factor score of the $\mathrm{PC}_{\mathrm{i}}$ and $b$ is the regression constant. The contribution rate $(W, \%)$ of each pollution source was calculated as follows:

$$
W=m_{i} / \sum m_{i} \times 100 \%
$$

Where $i$ is the pollution source represented by each principal component; $m_{i}$ is the regression coefficient corresponding to source $i$.

$\mathrm{BaP}$ toxic equivalent concentration $\left(\mathrm{BaP}_{\mathrm{eq}}\right)$ has been widely accepted and used to estimate the carcinogenic toxic risks of PAHs [24]. It was calculated and estimated based on the toxic equivalency factors (TEFs) that have been compiled by Tsai et al. (2004) [25]. The $\mathrm{BaP}_{\text {eq }}$ of each sample was calculated as follows:

$$
B a P_{e q}=\sum_{1}^{16} T E Q_{i}=\sum_{1}^{16} C_{i} \times T E F_{i}
$$

Where, $\mathrm{BaP}_{e q}$ is the toxic equivalent concentration of $\mathrm{BaP}$ in each sample (ng/g); $\mathrm{TEQ}_{i}$ is the equivalent concentration of the $\mathrm{i}$-th individual $\mathrm{PAH}(\mathrm{ng} / \mathrm{g}) ; C_{i}$ is the concentration of the i-th individual PAH (ng/g), and $\mathrm{TEF}_{i}$ is the corresponding toxic equivalent factor of the i-th PAH relative to $\mathrm{BaP}$ (Table 4).
In addition, statistical analyses including correlation analysis, PCA-MRL, and descriptive statistics were implemented using IBM SPSS Statistics 21.0, and data graphical plots were conducted using Origin 8.0. The inverse distance weighted (IDW) map showing the spatial distribution of $\sum_{16}$ PAHs was carried out with ArcGIS 10.4.

\section{Results and Discussion}

\section{Concentrations and Pollution Levels of PAHs}

Total concentrations of sixteen US EPA prioritylisted PAHs $\left(\Sigma_{16}\right.$ PAHs) in main urban area soils of Changchun were in the range of 46.6-8870.8 ng/g, with a mean value of $1480.1 \mathrm{ng} / \mathrm{g}$, which are nearly 10 times higher than those in the background area soils (Table 2). The mass concentration of $\Sigma_{7 \mathrm{car}} \mathrm{PAH}$ (Sum of 7 carcinogenic PAHs including $\mathrm{BaA}, \mathrm{Chr}, \mathrm{BbF}, \mathrm{BkF}$, $\mathrm{BaP}$, IcdP, and DBahA) ranged from 21.6 to $6056.1 \mathrm{ng} / \mathrm{g}$, with a mean value of $908.1 \mathrm{ng} / \mathrm{g}$, accounting for $61.3 \%$ of $\Sigma_{16}$ PAHs. According to the contamination classification system recommended by Maliszewska-Kordybach (1996) [26]: noncontaminated ( $\left.\Sigma_{16} \mathrm{PAHs}<200 \mathrm{ng} / \mathrm{g}\right)$; weakly contaminated (200 ng/g $<\Sigma_{16} \mathrm{PAHs}<600 \mathrm{ng} / \mathrm{g}$ ); moderate contaminated (600 ng/g $<\Sigma_{16} \mathrm{PAHs}<1000 \mathrm{ng} / \mathrm{g}$ )

\begin{tabular}{|c|c|c|c|c|c|c|c|c|c|c|}
\hline \multirow{2}{*}{ Compounds } & \multicolumn{4}{|c|}{ Changchun city $(52)^{\mathrm{k}}$} & \multicolumn{3}{|c|}{ Main urban area $(48)^{\mathrm{k}}$} & \multicolumn{3}{|c|}{ Background area $(4)^{\mathrm{k}}$} \\
\hline & Min & Max & Mean & $\mathrm{SD}^{\mathrm{b}}$ & Mean $_{1}$ & $\mathrm{SD}_{1}^{\mathrm{b}}$ & $\mathrm{CV}_{1}^{\mathrm{c}}$ & Mean $_{2}$ & $\mathrm{SD}_{2}^{\mathrm{b}}$ & $\mathrm{CV}_{2}^{\mathrm{c}}$ \\
\hline Nap & n.d. ${ }^{\mathrm{a}}$ & 44.9 & 7.7 & 7.8 & 7.6 & 8.2 & $108 \%$ & 8.9 & 1.1 & $12 \%$ \\
\hline Acy & n.d. & 292.5 & 10.7 & 40.8 & 11.5 & 42.4 & $369 \%$ & 0.9 & 0.4 & $39 \%$ \\
\hline Ace & n.d. & 83.2 & 7.6 & 14.4 & 8.1 & 14.9 & $184 \%$ & 1.2 & 0.8 & $71 \%$ \\
\hline Flu & 0.4 & 194.3 & 12.4 & 28.1 & 13.2 & 29.1 & $221 \%$ & 3.4 & 3.9 & $115 \%$ \\
\hline Phe & n.d. & 313.2 & 56.3 & 81.0 & 60.2 & 83.1 & $138 \%$ & 8.7 & 4.9 & $56 \%$ \\
\hline Ant & n.d. & 312.6 & 55.7 & 77.1 & 59.6 & 79.1 & $133 \%$ & 8.8 & 5.5 & $62 \%$ \\
\hline Fla & n.d. & 1024.4 & 147.2 & 239.6 & 158.1 & 246.3 & $156 \%$ & 15.5 & 11.1 & $71 \%$ \\
\hline Pyr & 1.8 & 1046.1 & 157.4 & 247.7 & 169.2 & 254.4 & $150 \%$ & 16.0 & 10.2 & $64 \%$ \\
\hline $\mathrm{BaA}$ & 3.0 & 874.9 & 111.4 & 176.6 & 119.7 & 181.4 & $152 \%$ & 11.4 & 7.9 & $70 \%$ \\
\hline $\mathrm{Chr}$ & n.d. & 1556.1 & 143.3 & 251.1 & 153.5 & 258.8 & $169 \%$ & 20.8 & 14.3 & $69 \%$ \\
\hline $\mathrm{BbF}$ & n.d. & 1479.1 & 200.6 & 330.4 & 215.9 & 339.6 & $157 \%$ & 17.4 & 12.2 & $70 \%$ \\
\hline $\mathrm{BkF}$ & n.d. & 1394.4 & 209.0 & 334.6 & 225.1 & 343.5 & $153 \%$ & 16.2 & 11.5 & $71 \%$ \\
\hline $\mathrm{BaP}$ & 1.9 & 542.8 & 94.6 & 141.7 & 101.8 & 145.2 & $143 \%$ & 8.4 & 7.0 & $84 \%$ \\
\hline IcdP & n.d. & 478.8 & 73.4 & 108.2 & 79.0 & 110.9 & $140 \%$ & 7.3 & 6.4 & $89 \%$ \\
\hline $\mathrm{DB}(\mathrm{a}, \mathrm{h}) \mathrm{A}$ & n.d. & 74.4 & 12.5 & 18.2 & 13.2 & 18.8 & $142 \%$ & 4.2 & 5.9 & $142 \%$ \\
\hline BghiP & n.d. & 489.9 & 78.7 & 115.5 & 84.5 & 118.4 & $140 \%$ & 9.5 & 7.8 & $82 \%$ \\
\hline 2-ring $\mathrm{PAHs}^{\mathrm{d}}$ & 1.9 & 606.9 & 38.3 & 85.7 & 40.3 & 89.0 & $221 \%$ & 14.4 & 4.3 & $30 \%$ \\
\hline 3-ring $\mathrm{PAHs}^{\mathrm{e}}$ & 8.9 & 1523.3 & 259.2 & 366.9 & 278.0 & 376.0 & $135 \%$ & 33.0 & 21.2 & $64 \%$ \\
\hline 4-ring $\mathrm{PAHs}^{\mathrm{f}}$ & 21.7 & 6188.7 & 821.7 & 1287.1 & 883.3 & 1321. & $150 \%$ & 81.7 & 55.5 & $68 \%$ \\
\hline 5-ring $\mathrm{PAHs}^{\mathrm{g}}$ & 4.8 & 1094.6 & 180.5 & 264.7 & 193.9 & 271.3 & $140 \%$ & 19.8 & 17.9 & $91 \%$ \\
\hline
\end{tabular}

Table 2. Concentrations (ng/g, dry weight) of individual PAHs in urban surface soil of Changchun city, NE China. 
Table 2. Continued.

\begin{tabular}{|c|c|c|c|c|c|c|c|c|c|c|}
\hline 6-ring PAHs $^{\mathrm{h}}$ & n.d. & 489.9 & 78.7 & 115.5 & 84.5 & 118.4 & $140 \%$ & 9.5 & 7.8 & $82 \%$ \\
\hline$\Sigma_{16} \mathrm{PAHs}^{\mathrm{i}}$ & 46.6 & 8870.8 & 1378.4 & 2011.7 & 1480.1 & 2062 & $139 \%$ & 158.3 & 98.0 & $62 \%$ \\
\hline$\Sigma_{7}$ PAHs $^{\mathrm{g}}$ & 21.6 & 6056.1 & 844.8 & 1305.0 & 908.1 & 1339 & $148 \%$ & 85.5 & 57.9 & $68 \%$ \\
\hline
\end{tabular}

${ }^{a}$ n.d.: not detected, lower than the limit of detection, calculated as half value of the method detection limit for mean;

${ }^{\mathrm{b}} \mathrm{SD}$ : Standard Deviation; ${ }^{\mathrm{C} C V}$ : Coefficient of variation;

${ }^{\mathrm{d}}$ Two rings: sum of Nap, Acy, Ace and Flu; ${ }^{\mathrm{e}}$ Three rings: sum of Phe, Ant and Fla; ${ }^{\mathrm{f}}$ Four rings: sum of Pyr, BaA, Chr, BbF, and BkF; Five rings: sum of $\mathrm{BaP}$, IcdP, and $\mathrm{DB}(\mathrm{a}, \mathrm{h}) \mathrm{A} ;{ }^{\mathrm{h}} \mathrm{Six}$ rings: BghiP;

${ }^{\mathrm{i}} \Sigma_{16}$ PAHs: sixteen US EPA priority-listed PAHs;

${ }^{g} \Sigma_{7}$ PAHs: sum of 7 carcinogenic PAHs including BaA, Chr, BbF, BkF, BaP, IcdP, and DBahA.

${ }^{\mathrm{k}}()$ : The digit in brackets is the number of samples.

and heavily contaminated $\left(\Sigma_{16} \mathrm{PAHs}>1000 \mathrm{ng} / \mathrm{g}\right), 25 \%$ and $25 \%$ of Changchun main urban area sampling sites could be considered as noncontaminated and weakly contaminated, respectively. Whereas, $15 \%$ and $35 \%$ of the sampling sites would be considered as moderate contaminated and heavily contaminated and deserved further attention for their potential environmental and human health risks.

Levels of PAHs in urban surface soil from Changchun city were much higher than those in southern China and seaside cities, such as Hangzhou (611 ng/g), Shenzhen (360 ng/g), Nanjing (979.6 ng/g), Xian (1246 ng/g); Ulsan (960 ng/g) of Korea, Kumasi (442 ng/g) of Ghana; Viseu (169 ng/g) and Estarreja $(98 \mathrm{ng} / \mathrm{g})$ of Portugal (Table S1). As one of the inland capital cities of the largest province of coal consumer in China, domestic heating in winter and coal combustion from coal-fired power plants as well as coke oven used in metallurgy, iron, and steel mills, machine manufacturing was assigned as a crucial source of soil PAHs in Changchun. Meanwhile, the lower annual average temperature in Changchun compared with the southern cities of China also contributed to a relatively high level of PAHs in the urban soil. Similar levels of PAHs were found in Dalian (1104 ng/g) and Zhengzhou (1567 ng/g) city of China as their similar development structure of transportation and industry with Changchun. On the other hand, the concentrations of $\Sigma_{16} \mathrm{PAHs}$ in Changchun urban soils were lower than those megacities, such as Beijing (1802.6 ng/g),

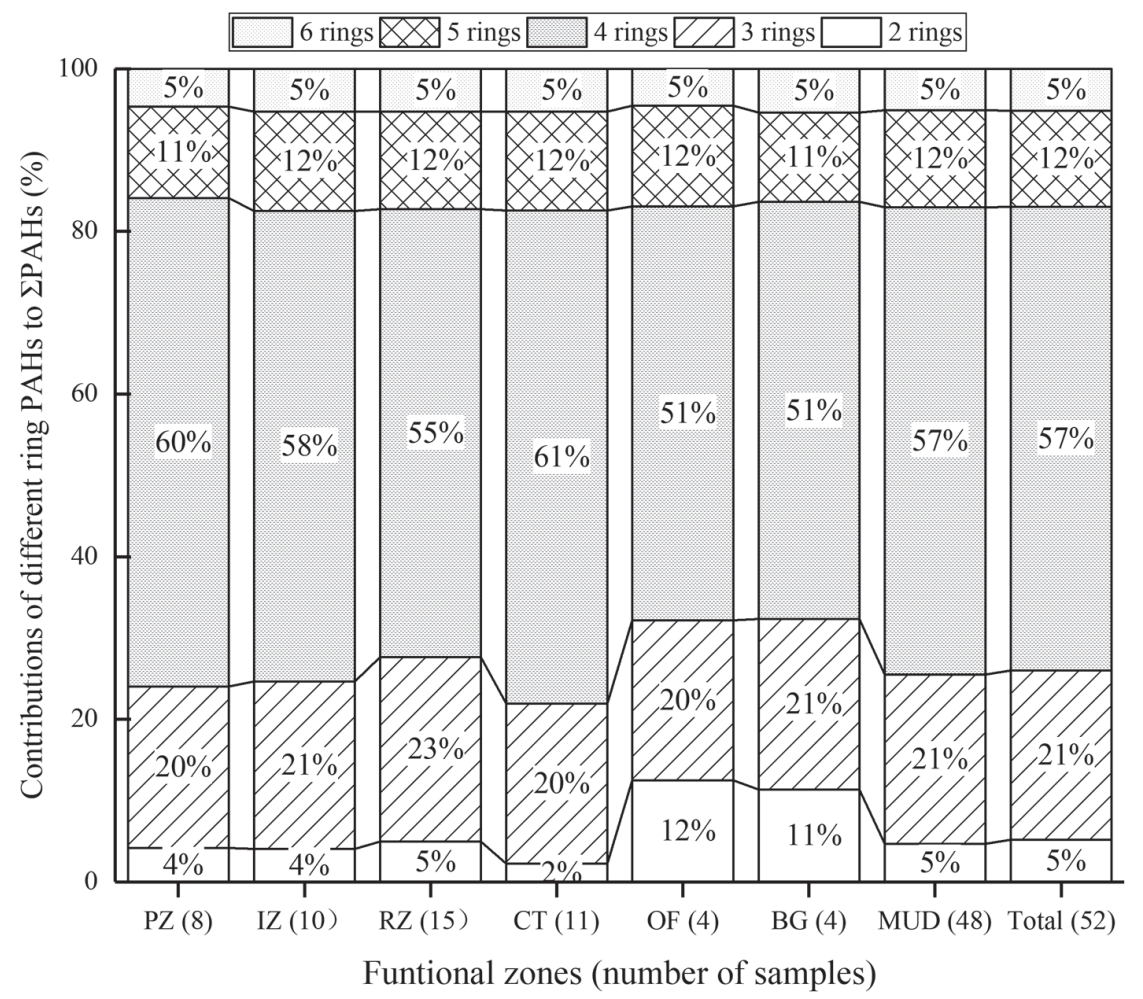

Fig. 2. Composition profiles plot of different ring PAHs in surface soils collected from the background (BG) area and different functional areas in main urban district (MUD), including park zone (PZ), industrial zone (IZ), residential zones (RZ), commercial traffic district (CT) and outskirt farmland (OF) of Changchun city, NE China. 
Shanghai (1970 ng/g), Lanzhou (2360 ng/g), Urumqi $(5018 \mathrm{ng} / \mathrm{g})$ of China; London (18000 ng/g) and Glasgow (11930 ng/g) of UK; Erbil (2296 ng/g) of Iraq and some other megacities with a comparatively larger population and heavier industries developed (Table S1). According to these comparison results, the PAHs pollution levels in Changchun urban soil are moderate and still should be paid enough attention.

\section{Composition and Distribution of PAHs}

The composition of different ring PAHs in different functional areas soils was exhibited in Fig 2. The 4-ring PAHs accounted for the majority (51.3\%$60.6 \%$, mean $57.0 \%$ ) of the total PAHs in all land used pattern soils of Changchun city, followed by the 3-ring PAHs (19.7\%-22.7\%, mean 20.9\%) and 5-ring PAHs (11.0\%-12.2\%, mean 11.8\%), which indicated that pyrogenic source may be the dominant PAH source in surface soil of Changchun city [6]. High molecular weight PAHs (HMW-PAHs, 4-6 rings) accounted for the majority $(67.6 \%-78.1 \%$, mean $74.0 \%)$ of the total PAHs in main urban area soils from CT, IZ, PZ, and $\mathrm{RZ}$, similar to the previous studies conducted in many cities [6, 12, 27]. These probably resulted from the higher persistence and the tendency to accumulate close to the emission sources of HMW-PAHs in soils [28]. It should be noted that a relatively high proportion of 2-ring PAHs was found in BG soil samples (11.4\%) and OF soil samples (12.6\%) compared with the soil samples from other functional areas, which can demonstrate that low molecular weight PAHs (LMW-PAHs, 2-3 rings) are more easily transported to remote areas via the atmosphere as their high volatility and low octanol- water partition coefficient [29]. For the individual compounds, $\mathrm{BkF}$ accounted for the highest proportion $(15.2 \%)$ of $\Sigma_{16}$ PAHs, then followed by BbF (14.6\%), Pyr (11.4\%), Fla (10.7\%), Chr (10.4\%), BaA (8.1\%) and BaP $(6.9 \%)$.

The coefficient of variation $(\mathrm{CV})$ can be used to exhibit spatial variation levels of PAHs in soil and strong anthropogenic activities usually correspond with a high level of CV [10]. PAHs contaminations in main urban area soils of Changchun city exhibited a strong spatial variability (CV>100\%) (Table 2), while weak variation $(\mathrm{CV}<100 \%)$ for individual PAHs (except Flu and DB(a,h)A) was shown in background area soils, which indicated PAHs in urban surface soils of Changchun were strongly affected by anthropogenic activities. Concentrations of PAHs in urban surface soils varied greatly among different land used areas in Changchun city (Fig 3). The mean concentrations of $\Sigma_{16}$ PAHs and $\Sigma_{7}$ PAHs all decreased in an order of CT $>$ IZ $>$ RZ $>$ PZ $>$ OF $>$ BG. Similar research also exhibited that the concentrations of soil PAHs in the industrial areas, commercial districts, and heavy traffic areas were higher [30]. These are mainly due to the large motor vehicles with heavy vehicle exhaust, dense population, and public catering services in commercial traffic districts, leading to an increase in PAHs emissions [31]. Meanwhile, the "running, leaking, dripping and leaking" of raw materials, power fuel, and lubricating oil in the process of industrial production also results in the high PAHs concentration in the urban soil of industrial areas.

The spatially interpolated distribution of $\Sigma_{16} \mathrm{PAHs}$ contamination in the main urban area soil of Changchun city was exhibited using the IDW interpolation in Fig.4.

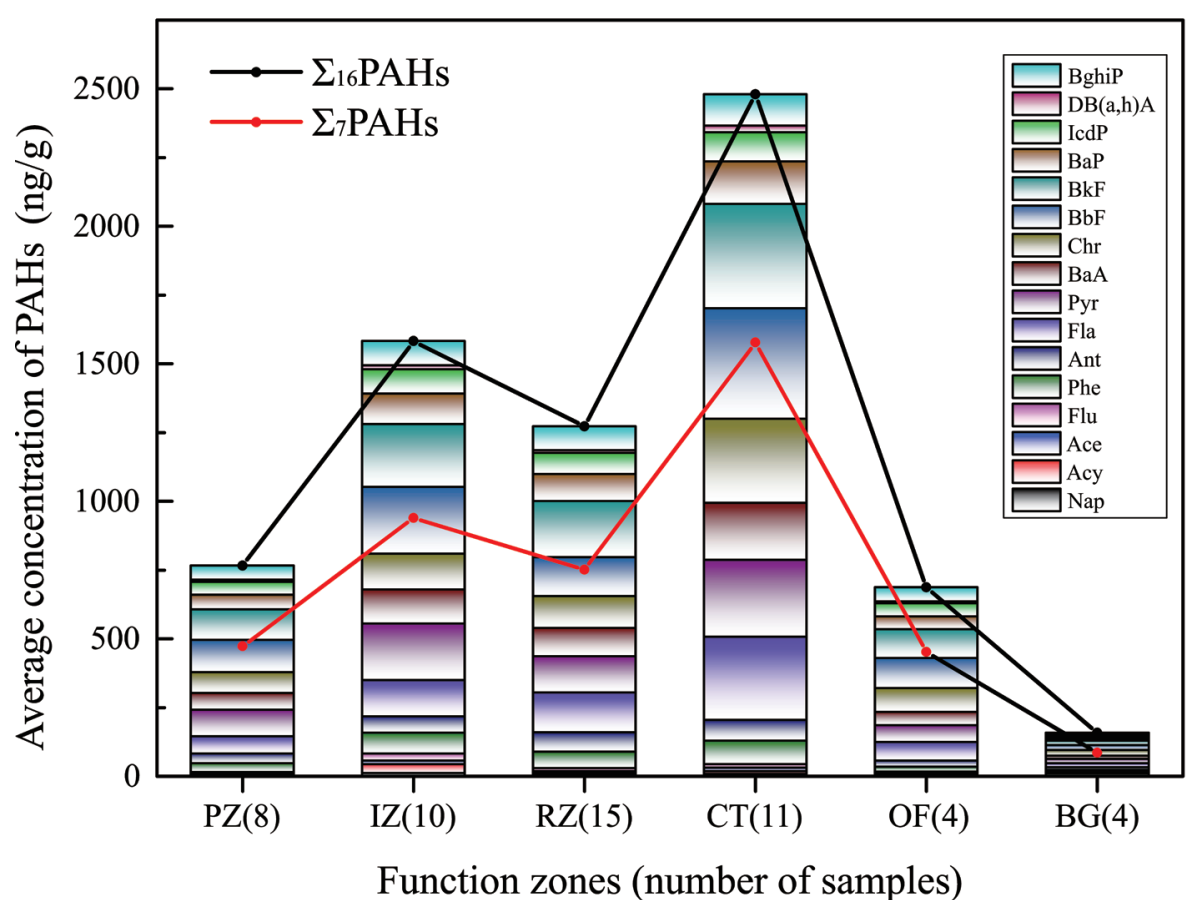

Fig. 3. Concentrations of PAHs in urban surface soils among different land used areas of Changchun city, NE China. 


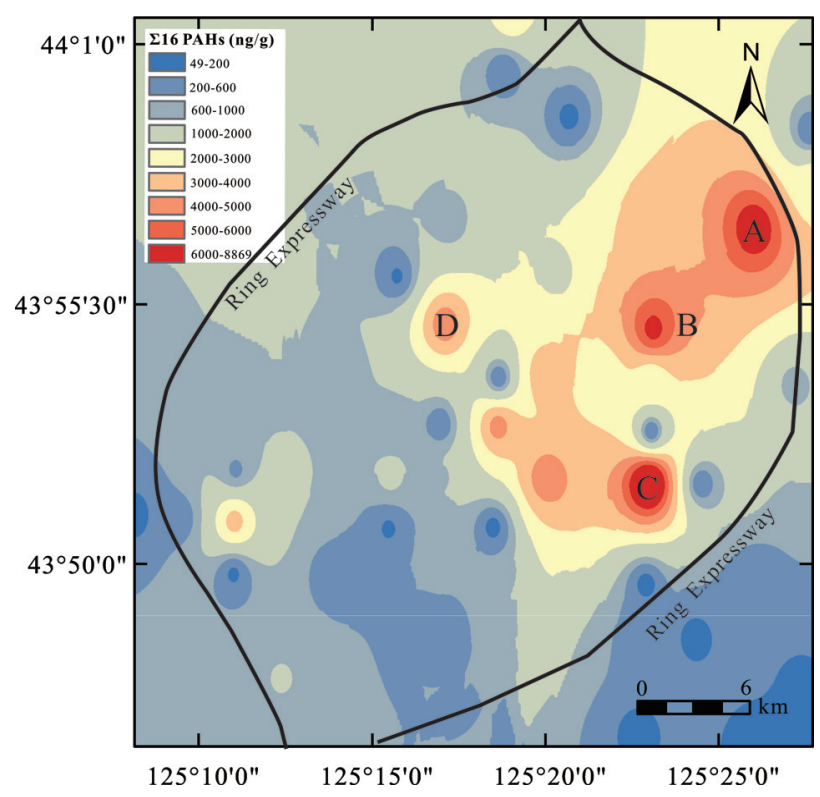

Fig. 4. Concentrations of PAHs in urban surface soils among different land used areas of Changchun city, NE China.

A relatively high concentration of $\Sigma_{16}$ PAHs in soil was recorded in the northeast region and the central historic district of Changchun city, similar to the results from the previous study on the distribution of PAHs in vegetable soils in Changchun suburb [32]. The northern and eastern portions of the city have been mainly dominated by the coal-fired power plants, metallurgy plants, iron, and steel mills and large numbers of cement plants [13] and the central historic district of the city have experienced substantial development with the higher residential and commercial activities and traffic levels over the past decades. Liu et al. (2010) found that PAHs concentrations in the soils from old urban areas were high due to the process of longterm artificial accumulation [33]. Four sections with hotspots showed the highest concentrations of PAHs in Changchun urban soils which approach the major emission sources of PAHs geographically. Section A and D are located in the IZ surrounding the machinery plants, biopharmaceutical factories, and the coal-fired power plants; Sections B and C are located in the CT which is around complex vehicle traffic and commercial activities, such as lots of building material markets and catering services. It should be noted that the prevalence of southwest wind in Changchun throughout the year may also result in the migration of atmosphere PAHs with the wind force action and deposited into the soils in the northeast region.

\section{Correlation Analysis between PAHs and Soil Basic Properties}

PAHs residues in soil often bind with soil organic matter as their hydrophobicity and lipophilicity. Once deposited into the soil, most PAHs will be absorbed by soil organic matter and the strong sorption will inhibit their degradation and leaching [21]. Therefore, the soil organic matter, especially the soil total organic carbon (TOC) is considered to be a very important factor related to soil PAHs pollution. Previous research had shown a high positive correlation between soil TOC and PAHs residues [34]. To further identify the impacts of TOC on soil PAHs pollution in this study, Pearson's correlation analysis was applied to evaluate the relationship among the individual PAHs and soil TOC (Table S2, Supplementary material). Soil TOC varied from $0.56 \%$ to $4.79 \%$, with a mean of $1.63 \%$. Pearson's correlation coefficients between soil properties ( $\mathrm{pH}$ and TOC) and PAHs showed that there was a significantly positive correlation between soil TOC and $\Sigma_{16}$ PAHs $(\mathrm{r}=0.408, p<0.01), \Sigma_{7}$ PAHs $(\mathrm{r}=0.427, p<0.01)$, ¿LMWPAHs $(\mathrm{r}=0.301, p<0.05)$ and $\Sigma$ HMWPAHs $(\mathrm{r}=0.423, p<0.01)$, but poorly related with soil $\mathrm{pH}$ in urban soil from Changchun. Individual PAHs (except Acy, Ace, Flu, Ant, and $\mathrm{Chr}$ ) were also positively correlated with TOC $(0.275 \leq \mathrm{r} \leq 0.539, \quad p<0.05)$. The results of the above correlation analysis further certificate that TOC is a key factor affecting the fate of PAHs in soil, especially for high molecular weight PAHs in soil.

\section{Source Identifications and Contributions}

Identifying the potential sources of soil PAHs is essential for assessing the environmental risk and controlling the environmental pollution of PAHs [21]. PAHs emitted from different sources would exhibit different molecular compositions [35]. Generally, LMW-PAHs (2-3 rings) mainly result from petroleum pollution, and HMW-PAHs (4-6 rings) are always related to the incomplete combustion of coal, wood, and petroleum products as well as vehicle emissions [36]. Therefore, the ratio of LMW-PAHs to HMW-PAHs can be used to identify pyrogenic $(<1)$ and petrogenic $(>1)$ sources of PAHs in soils [37]. In this study, the ratio of LMW-PAHs to HMW-PAHs was far below 1, which can preliminarily conjecture that pyrogenic source related to combustion was the dominant source for PAHs in the urban surface soils of Changchun.

PAHs molecular diagnostic ratios can effectively provide specific source identification information as the pairs of PAHs with the same molar mass and similar physicochemical properties are often emitted as a group under different combustion conditions [38-39]. According to the previous reports, a ratio of Ant $/($ Ant + Phe $)<0.1$ indicates the petrogenic sources (crude oil or raw coal) and that $>0.1$ indicates the pyrogenic sources [40]. Meanwhile, $\mathrm{BaA} /(\mathrm{BaA}+\mathrm{Chr})$ $<0.2$ demonstrates petrogenic source; 0.2-0.35 indicates mixed pyrogenic sourcing including incomplete combustion of coal and biomass (such as wood or grass) and $>0.35$ suggests petroleum combustion [36]. In addition, both ratios of $\mathrm{IcdP} /(\mathrm{IcdP}+\mathrm{BghiP})<0.20$ and $\mathrm{Fla} /(\mathrm{Fla}+\mathrm{Pyr})<0.4$ likely imply the petrogenic sources, whereas $0.2-0.5$ and $0.4-0.5$ of these two ratios indicate 

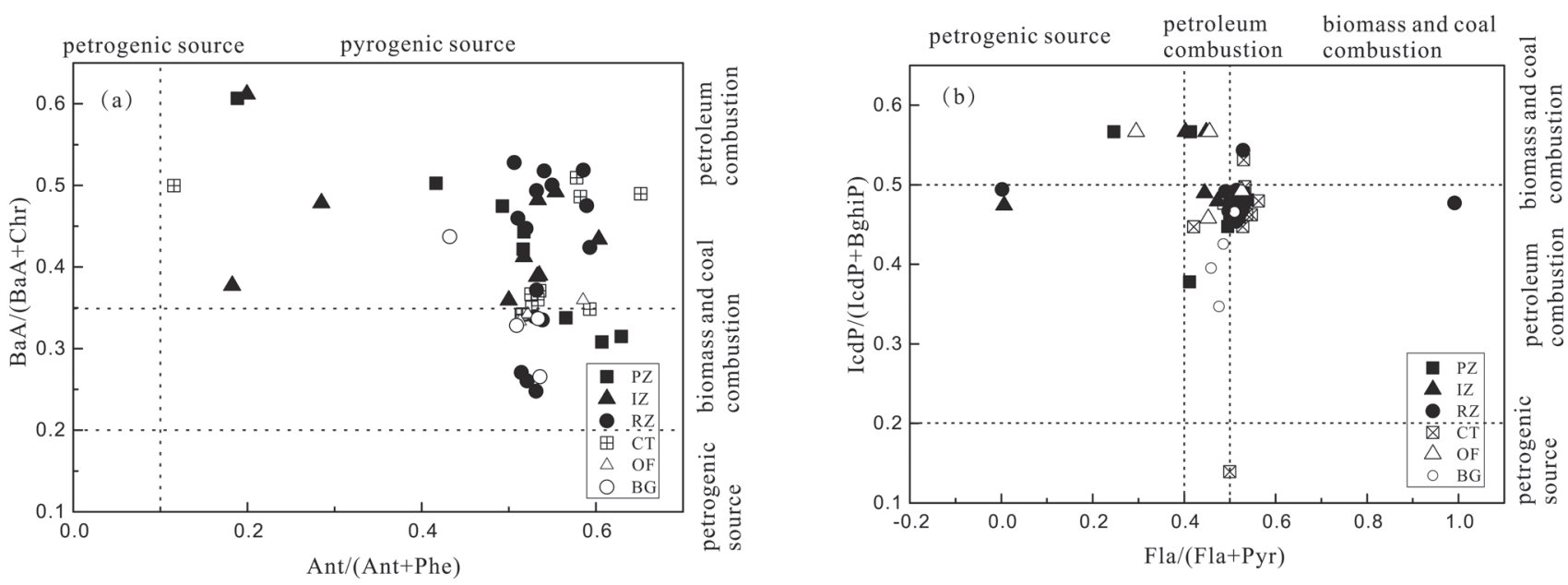

Fig. 5. Diagnostic ratios for source analysis of PAHs in the surface soil of Changchun city, NE China

petroleum combustion sources, respectively, and $>0.5$ of these two ratios both suggest the incomplete combustion of coal and biomass. In this study, the above four PAHs molecular diagnostic ratios of all 52 sampling sites from Changchun city were calculated and plotted in Fig 5. The ratios of Ant/(Ant+Phe) and $\mathrm{BaA} /(\mathrm{BaA}+\mathrm{Chr})$ were ranged from 0.10 to 0.65 and from 0.25 to 0.61 respectively, indicating that pyrogenic sources were dominant for PAHs in surface soils. $65 \%$ of sampling sites including nearly all industrial zone and commercial traffic area and some residential and park zone samples exhibited the petroleum combustion sources, the remaining $35 \%$ sampling sites contained background samples, some park, and residential samples showed the signature of biomass and coal combustion sources. On the other hand, the ratios of $\mathrm{Fla} /(\mathrm{Fla}+\mathrm{Pyr})$ and $\mathrm{IcdP} /(\mathrm{IcdP}+\mathrm{BghiP})$ ranged from 0 to 0.48 and 0.14 to 0.57 , respectively, suggesting that PAHs in urban soil from Changchun were primarily derived from petroleum combustion sources, biomass and coal combustion sources and the mixed sources of petroleum, biomass and coal combustion. Significantly, the petrogenic source may be also a contributor to the soil PAHs pollution in the main urban area of Changchun city.

Multivariate linear regression (MLR) analysis in combination with PCA allows quantitatively apportioning the relative contributions of various identified sources to the total sum of pollutants. In this study, PCA subjected to the normal-varimax rotation of Kaiser standardization was performed on 16 PAHs of 52 samples. Before the interpretation of results, Kaiser-Meyer-Olkin (KMO) and Bartlett's sphericity tests were performed to examine the validity of PCA. KMO and Bartlett's test results were 0.76 and 2257.96, respectively $(d f=120, p<0.01)$, indicating that PCA may be a valuable tool in the discrimination of distinct PAHs sources [24]. Four principal components of PC1, $\mathrm{PC} 2, \mathrm{PC} 3$, and $\mathrm{PC} 4$ with the rotated eigenvalue $>1$ were extracted, which have cumulatively explained $95.68 \%$ of the total variance. For each factor, the PAHs with relatively high loadings are marked in bold in Table 3. $\mathrm{PC} 1$ accounts for $47.12 \%$ of the total variance and is highly loaded by BghiP, IcdP, BaP, Ant, BkF, BaA, Chr, Pyr, BbF, DBahA, Phe. Among these PAHs, BghiP, $\mathrm{BaP}$, IcdP, Chr, and DBahA have been identified as typical tracers of vehicular PAHs [41]. BaA, BaP, and BghiP are typical makers of petroleum combustion [42]. $\mathrm{BkF}$ is usually derived from diesel-powered vehicles and BghiP is predominated from the gasoline engine emission [34]. Whereas, Phe, Ant, Pyr, BaA, BbF, and $\mathrm{BkF}$ are markers for fuel and coal combustion [43-44]. Changchun has one of the largest transportation hubs and is an industrial manufacturing center dominated by automobiles industries, electricity-thermal production, and coal is one of the most important industrial energy. In addition, Changchun is the cradle of the automobile industry and rail transit manufacturing industry and the car parc of Changchun has reached 2.10 million in 2019 [15]. Thus, PC1 was identified as a mixed source contribution from fossil fuel combustion emission and the traffic emission. PC2 explained $20.76 \%$ of the total variance and was highly loaded by Acy, Ace, and Flu, which can be interpreted as the coking and biomass burning source. This is because Acy and Ace are the dominant $\mathrm{PAH}$ compounds released during wood and biomass burning, and Flu is a typical marker for coke oven source [45]. In 2019, the consumption amount of coke and other coke products for industrial production in Changchun has reached 9100 tons. Biomass waste as fuel is mainly used for thermal power and heating and the consumption amount achieved 132722 tons of SCE in 2019 [15]. PC3 explained $18.89 \%$ of the total variance with a heavier loading of Fla and the relatively high loadings of BbF and Pyr. Pyr and Fla are typical representative markers for coal combustion [46], therefore, PC3 was deduced to represent the coal combustion source. PC4 with the highest loading of Nap contributed $8.91 \%$ of the total variance. Nap is a kind of volatile PAH associated with the evaporation of 
Table 3. Varimax normalized matrix of 16 PAHs in the surface soils from Changchun city.

\begin{tabular}{|c|c|c|c|c|}
\hline \multirow{2}{*}{ PAH compounds } & \multicolumn{4}{|c|}{ Principal components } \\
\hline & PC 1 & PC 2 & PC 3 & PC 4 \\
\hline Nap & 0.176 & 0.473 & 0.147 & 0.834 \\
\hline Acy & 0.071 & 0.974 & 0.014 & 0.133 \\
\hline Ace & 0.315 & 0.737 & 0.456 & 0.322 \\
\hline Flu & 0.223 & 0.938 & 0.213 & 0.137 \\
\hline Phe & 0.697 & 0.495 & 0.393 & 0.267 \\
\hline Ant & 0.872 & 0.141 & 0.323 & -0.158 \\
\hline Fla & 0.381 & 0.384 & 0.782 & 0.07 \\
\hline Pyr & 0.689 & 0.269 & 0.557 & 0.252 \\
\hline $\mathrm{BaA}$ & 0.812 & 0.158 & 0.515 & 0.158 \\
\hline $\mathrm{Chr}$ & 0.727 & 0.029 & 0.600 & 0.002 \\
\hline $\mathrm{BbF}$ & 0.660 & 0.152 & 0.646 & 0.31 \\
\hline $\mathrm{BkF}$ & 0.856 & 0.168 & 0.383 & 0.225 \\
\hline $\mathrm{BaP}$ & 0.885 & 0.24 & 0.275 & 0.261 \\
\hline IcdP & 0.948 & 0.218 & 0.146 & 0.161 \\
\hline DBahA & 0.716 & 0.172 & 0.514 & 0.39 \\
\hline BghiP & 0.969 & 0.17 & 0.125 & 0.091 \\
\hline Eigenvalue & 7.539 & 3.321 & 3.023 & 1.426 \\
\hline$\%$ of Variance & $47.12 \%$ & $20.76 \%$ & $18.89 \%$ & $8.91 \%$ \\
\hline Cumulative \% & $47.12 \%$ & $67.88 \%$ & $86.77 \%$ & $95.68 \%$ \\
\hline
\end{tabular}

Note: The bold data $(>0.500)$ represents a higher weightage of PAH.

petroleum products during fuel handing and refueling operations.

In order to further analyze the relative contributions of various sources quantitatively, the standardized PCA factor scores and the standardized $\Sigma_{16} \mathrm{PAHs}$ concentrations were used as the independent and dependent variables, respectively, for the multivariate linear regression. The regression was run using a forward stepwise method under the significance level of 0.05 using IBM SPSS Statistics 21.0. The obtained regression equation was expressed as follows:

$$
\begin{gathered}
Z_{P A H s}=0.787 f_{1}+0.255 f_{2}+0.526 f_{3}+0.192 f_{4} \\
\left(R^{2}=0.998, p<0.001\right)
\end{gathered}
$$

Where, $Z_{P A H S}$ were the standardized concentration of $\Sigma_{16} \mathrm{PAHs} ; f_{1-4}$ were the standardized factor scores of $P C_{1-4} ; R^{2}$ was the obtained decision coefficients; $p$ was the conditional probability of model significance test.

The obtained decision coefficient of the regression model was 0.998 , which indicated a good fit goodness of the regression equation. Source contributions from the four PCs to the total PAH burden in Changchun urban surface soil could be calculated from the standardized factor regression coefficients according to the calculation method described in Data analyses method, and the results are presented in Table 4. PC 1 (mixed sources of fossil fuel combustion emission and vehicular emission), PC 2 (coking and biomass burning), and PC 3 (coal combustion) contributed over $44.72 \%, 14.19 \%$ and $29.89 \%$ of the total PAH source to the city surface soil, respectively. The remaining $10.91 \%$ source of PC 4 may come from evaporative and leakage of petroleum products.

For further verifying the reliability of the PCA-MLR source apportionment method and exploring the spatial distribution of PAHs pollution sources in the main urban area of Changchun city, the spatially interpolated distribution for the four principal components factor scores was conducted using the IDW interpolation in Fig. 6. As the first major source of soil PAHs contamination, the mixed sources (PC1) containing fossil fuel combustion emission and vehicular emission exhibited the most similar distribution characteristics with the PAHs contaminations in the central historic district and northeast portions of Changchun city, and the mixed sources (PC1) corresponding to the PAHs contamination hotspot of section A in Fig. 5. Similarly, the coal combustion source (PC3) is the second-largest soil PAHs contamination source mainly corresponding to the hotspot of section $\mathrm{C}$ surrounding the thermal power plants in the southeast region. Coking and biomass burning sources (PC2) and petroleum sources (PC4) can be considered as the main sources of the hotspots of section D and section B, respectively. The spatial distribution of the principal components factor scores can well correspond to the area with high PAHs contaminations, which also indicated the effectiveness of PCA-MLR for source apportionment in urban soil PAHs pollution.

Table 4. Multiple regression statistics using standardized factor scores of four principal components for PAHs.

\begin{tabular}{|c|c|c|c|c|}
\hline PCs & Representative source & $\begin{array}{c}\text { Standardized } \\
\text { regression coefficients }\end{array}$ & $\begin{array}{c}\text { Source } \\
\text { contribution }\end{array}$ & $\begin{array}{c}\text { Decision } \\
\text { coefficients }\end{array}$ \\
\hline PC1 & Mixed sources of fossil fuel combustion emission and vehicular emission & 0.787 & $44.72 \%$ & \\
\hline PC2 & Coking and biomass burning source & 0.255 & $14.19 \%$ & 0.998 \\
\hline PC3 & Coal combustion source & 0.526 & $29.89 \%$ & \\
\hline PC4 & Petroleum source & 0.192 & $10.91 \%$ & \\
\hline
\end{tabular}



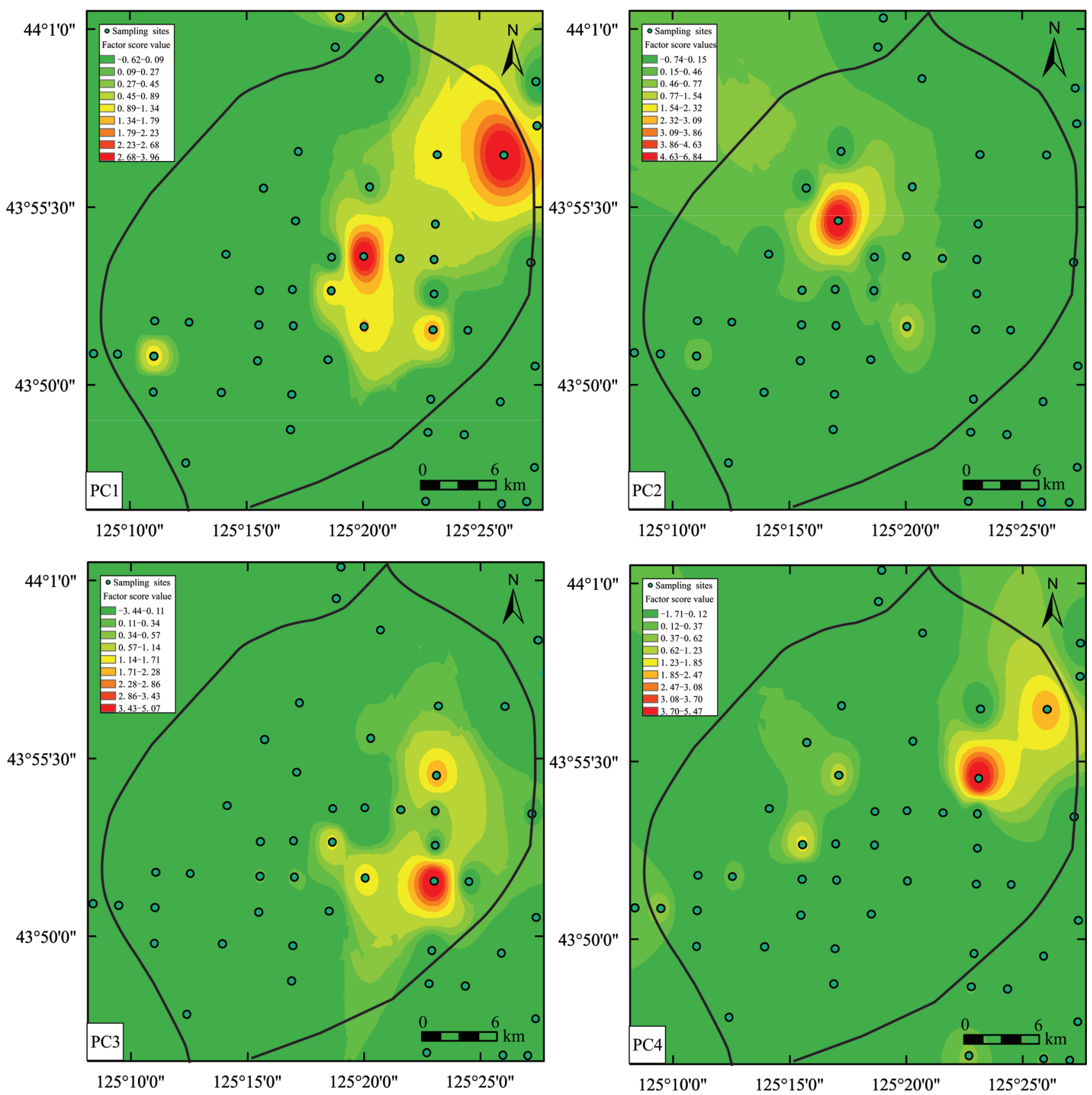

Fig. 6. Spatial distribution of the four principal components factor scores in main urban district soils of Changchun city, NE China.

\section{Toxicity Risk Assessment of PAHs}

The potential toxicity of PAHs depends on the natural toxicity of PAHs and their concentration [22], the total $\mathrm{BaP}_{\mathrm{eq}}$ of $16 \mathrm{PAHs}$ in soil samples ranged from 2.42 to $980.25 \mathrm{ng} / \mathrm{g}$, and the mean concentration in main urban area soils and background soils was 181.79 and $17.18 \mathrm{ng} / \mathrm{g}$, respectively. The total $\mathrm{BaP}_{\mathrm{eq}}$ of 7 carcinogenic PAHs was approximately that of 16 PAHs, and accounted for $98.97 \%$ contributions of the total $\mathrm{BaP}_{\text {eq }}$ of 16 PAHs (Table 5), suggesting that the 7 carcinogenic PAHs were the primary contributors to the total carcinogenic potency of the PAHs in the soil samples, and among which $\mathrm{BaP}$ was the largest contributor with an average contribution rate of $55.94 \%$, followed by $\mathrm{BkF}(12.36 \%), \mathrm{BbF}(11.84 \%)$, $\mathrm{DB}(\mathrm{a}, \mathrm{h}) \mathrm{A}$ $(7.08 \%)$ and $\mathrm{BaA}(6.59 \%)$. A strong correlation between $\mathrm{BaP}_{\text {eq }}$ values and the concentrations of $\Sigma_{16} \mathrm{PAHs}$ in Changchun city soils $\left(r^{2}>0.96\right)$ was found (Fig. 7). The comparison of the toxic equivalent concentrations of PAHs in different land used areas (Fig. 8) exhibited that the concentrations of $\mathrm{BaP}_{\mathrm{eq}}$ in commercial traffic district soils were highest, followed by industrial zone soils and those in background soils were lowest, which is corresponded to the comparison result of the PAHs concentrations in different land used areas.

The total $\mathrm{BaP}_{\mathrm{eq}}$ concentration of $16 \mathrm{PAHs}$ in Changchun urban soil was lower than that in urban soil of Shanghai, China (236 ng/g) [27], Lisbon, Portugal (229 ng/g) [12], Sydney, Australia (440 ng/g) [22] 
Table 5. Total toxic equivalent concentrations of PAHs (ng/g) in surface soil of Changchun city, NE China.

\begin{tabular}{|c|c|c|c|c|c|c|}
\hline \multirow{2}{*}{ Compounds } & \multirow{2}{*}{$\mathrm{TEF}^{\mathrm{a}}$} & \multirow{2}{*}{ Carcinogenic group } & \multicolumn{3}{|c|}{$\mathrm{BaP}_{\mathrm{eq}}(\mathrm{ng} / \mathrm{g})$} & \multirow{2}{*}{$\begin{array}{l}\text { Toxicity contribution } \\
\text { rate }\end{array}$} \\
\hline & & & Concentration range & Mean $_{1}{ }^{\mathrm{c}}$ & $\operatorname{Mean}_{2}{ }^{\mathrm{d}}$ & \\
\hline Nap & 0.001 & $2 \mathrm{~B}$ & $0-0.05$ & 0.01 & 0.01 & $0.00 \%$ \\
\hline Acy & 0.001 & 3 & $0-0.29$ & 0.01 & 0.00 & $0.01 \%$ \\
\hline Ace & 0.001 & 3 & $0-0.08$ & 0.01 & 0.00 & $0.00 \%$ \\
\hline Flu & 0.001 & 3 & $0-0.19$ & 0.01 & 0.00 & $0.01 \%$ \\
\hline Phe & 0.001 & 3 & $0.003-0.31$ & 0.06 & 0.01 & $0.03 \%$ \\
\hline Ant & 0.01 & 3 & $0-3.13$ & 0.60 & 0.09 & $0.33 \%$ \\
\hline Fla & 0.001 & 3 & $0-1.02$ & 0.16 & 0.02 & $0.09 \%$ \\
\hline Pyr & 0.001 & 3 & $0-1.05$ & 0.17 & 0.02 & $0.09 \%$ \\
\hline $\mathrm{BaA}$ & 0.01 & $2 \mathrm{~B}$ & $0.30-87.49$ & 11.97 & 1.14 & $6.59 \%$ \\
\hline $\mathrm{Chr}$ & 0.1 & $2 \mathrm{~B}$ & $0.05-15.56$ & 1.53 & 021 & $0.85 \%$ \\
\hline $\mathrm{BbF}$ & 0.1 & $2 \mathrm{~B}$ & $0-147.91$ & 21.54 & 1.74 & $11.84 \%$ \\
\hline $\mathrm{BkF}$ & 0.1 & $2 \mathrm{~B}$ & $0-139.44$ & 22.51 & 1.62 & $12.36 \%$ \\
\hline $\mathrm{BaP}$ & 1 & 1 & $1.90-542.80$ & 101.79 & 8.35 & $55.94 \%$ \\
\hline IcdP & 0.1 & $2 \mathrm{~B}$ & $0-47.88$ & 7.87 & 0.64 & $4.32 \%$ \\
\hline DBahA & 1 & $2 \mathrm{~A}$ & $0-74.4$ & 12.71 & 3.25 & $7.08 \%$ \\
\hline BghiP & 0.01 & 3 & $0-4.90$ & 0.84 & 0.09 & $0.46 \%$ \\
\hline$\Sigma_{16} \mathrm{Bap}_{\mathrm{eq}}{ }^{\mathrm{e}}$ & - & - & $2.42-980.25$ & 181.79 & 17.18 & $100.00 \%$ \\
\hline$\Sigma_{7 \text { car }} \mathrm{Bap}_{\mathrm{eq}}{ }^{\mathrm{f}}$ & - & - & $2.29-971.05$ & 179.92 & 16.95 & $98.97 \%$ \\
\hline
\end{tabular}

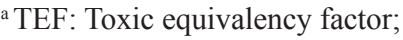

b 1: intensely carcinogenic to humans; 2A: probably carcinogenic to humans; 2B: possibly carcinogenic to humans; 3 : not classifiable as to its carcinogenicity to humans; D: inadequate information to assess carcinogenic potential

${ }^{\mathrm{c}}$ mean $_{1}$ : Average concentration in build-up area soils; ${ }^{\mathrm{d}}$ mean $_{2}$ : Average concentration in background soils;

${ }^{\mathrm{e}} \Sigma_{16} \mathrm{Bap}_{\mathrm{eq}}$ : Sum of the 16 US EPA identified PAHs as priority-listed controlled environmental pollutants;

${ }^{\mathrm{f}} \Sigma_{7 \mathrm{car}} \mathrm{Bap}_{\mathrm{eq}}:$ Sum of 7 carcinogenic PAHs including BaA, Chr, BbF, BkF, BaP, IcdP, and DBahA.

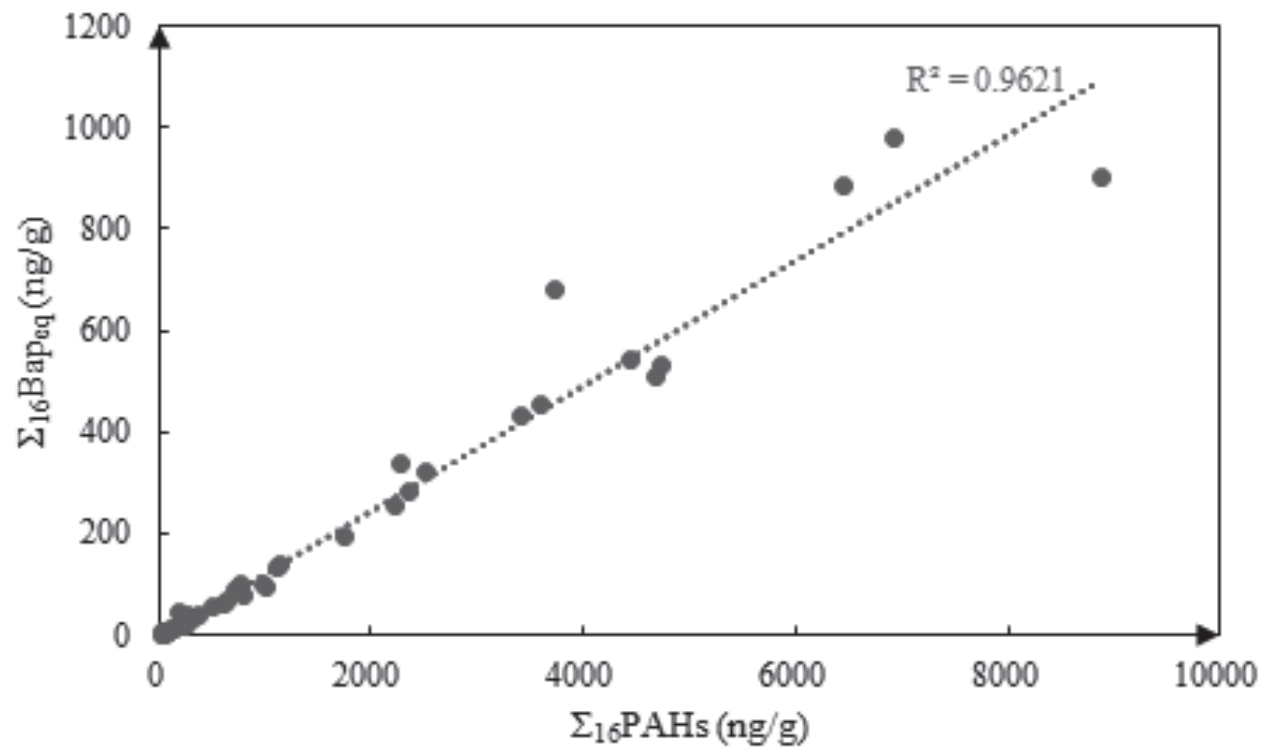

Fig. 7. Correlation between toxic equivalent concentration $\left(\mathrm{Bap}_{\mathrm{eq}}\right)$ and total of 16 PAHs in surface soils of Changchun city, NE China $(\mathrm{n}=52)$. 


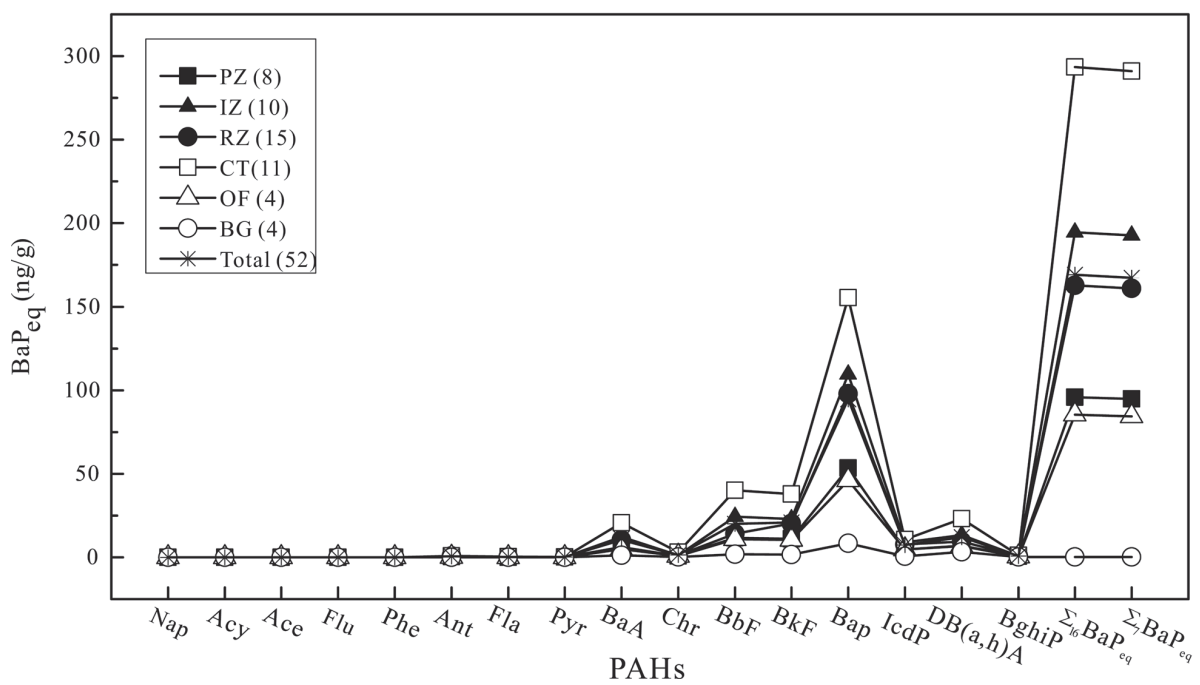

Fig. 8. Comparison of $\mathrm{BaP}_{\mathrm{eq}}$ for $16 \mathrm{PAHs}$ in urban surface soils among different land used areas of Changchun city, NE China (The digit in brackets represents the number of sampling sites).

and that found in Orlando and Tampa city, Florida, USA (4-3742 (452) ng/g and n.d.-9706(802) ng/g) [6]; while similar to the level found in Beijing, China (180.7 ng/g) [33], Nanjing, China (193.9 ng/g) [47], but higher than that in Lanzhou, China (5.93-205(136) ng/g) [34], Erbil, Iraq (3.26-362.84 (174.32) ng/g) [48], Kumasi, Ghana (1.24-188.2 ng/g) [11]. Compared with the average $\mathrm{BaP}_{\text {eq }}$ concentrations of the $\Sigma_{16} \mathrm{PAHs}$ in urban soils in China (191.55 ng/g) [49], 30\% of the soil samples in Changchun city had $\mathrm{BaP}_{\mathrm{eq}}$ concentrations that exceeded the average value of urban soils in China. Canadian Soil Quality Guidelines provide a $\mathrm{BaP}_{\mathrm{eq}}$ reference guideline of $600 \mathrm{ng} / \mathrm{g}$ based on the PAHs' carcinogenic effects for the protection of the environment and human health [50]. Among 48 urban soil samples, 4 samples including $1 \mathrm{RZ}$ sample in the central historic district, 2 CT samples, and 1 IZ sample nearby building materials markets in the east of the city had concentrations exceeding the safety value. The above results suggest that the potential toxic risk for exposure to soil PAHs in Changchun city was moderate, while the carcinogenic potency of PAHs still poses serious potential health risks in some sampling sites.

\section{Conclusions}

Significant differences (at least one order of magnitude) were observed in $\Sigma_{16} \mathrm{PAH}$ concentrations between main urban area soils and background area soils of Changchun city, which indicated the intensive anthropogenic activities were a key factor resulting in the continuous and increased emissions of potentially toxic PAHs in the urban soil environment.4 ring PAHs accounted for the majority $(51.3 \%-60.6 \%)$ of the total PAHs in urban soils. For the individual PAHs, BkF, $\mathrm{BbF}$, Pyr, Fla, Chr, BaA, and BaP were the dominant constituents. The PAHs in the main urban area soils of Changchun city primarily derived from pyrogenic sources, especially coal, fossil fuel combustion, and vehicle emissions. Soil TOC was an important factor affecting the accumulation of PAHs according to the correlation analysis. Distribution maps demonstrated that higher concentrations of PAHs mainly concentrated in the northeast region with business districts and heavy traffic loads and the central historic district soils of Changchun city. The total $\mathrm{BaP}_{\text {eq }}$ of $16 \mathrm{PAHs}$ ranged from 2.42 to $980.25 \mathrm{ng} / \mathrm{g}$, with a mean value of $181.79 \mathrm{ng} / \mathrm{g}$. PAHs contaminations and their toxicity levels detected in main urban area soils of Changchun city are relatively moderate compared with other global cities, while $35 \%$ of the sampling sites would be considered contaminated with heavily PAHs (>1000 ng/g) based on the Maliszewska-Kordybach classification. Overall, this information demonstrates that some forms of considerable attention and remediation programs may be required for these heavily contaminated sampling sites to reduce their potential adverse health effect for residents exposed to harmful PAH contaminants.

\section{Acknowledgments}

The authors are grateful for the supports from the Agricultural Geology Projects of China Geological Survey (No.12120105111208), the State Key Research and Development Program (No.2016YFC0600606) in collecting, analyzing, interpreting data, and writing the manuscript.

\section{Conflict of Interest}

The authors declare no conflict of interest. 


\section{References}

1. CHENG Q.Q., GE W., CHAI C., WU J., MA D., ZENG L.S., ZHU X.W., CHEN Q.H., LI J.S. Polycyclic aromatic hydrocarbons in soil around coal-fired power plants in Shandong, China. Polish Journal of Environmental Studies, 28 (1), 53, 2019.

2. GOPE M., MASTO R.E., GEORGE J., BALACHANDRAN S. Exposure and cancer risk assessment of polycyclic aromatic hydrocarbons (PAHs) in the street dust of Asansol city, India. Sustainable Cities \& Society, 38, 616,2018.

3. KE C.L., GU Y.G., LIU Q. Polycyclic aromatic hydrocarbons (PAHs) in exposed-lawn soils from 28 urban parks in the megacity Guangzhou: Occurrence, sources, and human health implications. Archives Environmental Contamination \& Toxicology, 72 (4), 496, 2017.

4. LEMIEUX C.L., LONG A.S., LAMBERT I.B., LUNDSTEDT S., TYSKLIND M., WHITE P. A. Cancer risk assessment of polycyclic aromatic hydrocarbon contaminated soils determined using bioassay-derived levels of benzo[a]pyrene equivalents. Environmental Science \& Technology, 49 (3), 1797,2015.

5. USA EPA (US Environmental Protection Agency). Priority Pollutant List. Available online: http://www.epa.gov/sites/ production/files/2015-09/documents/prioritypollutant-listepa.pdf (2015).

6. LIU Y.G., GAO P., SU J., DA SILVA E.B., DE OLIVERIA L.M., TOWNSEND T., XIANG P., MA L.Q. PAHs in urban soils of two Florida cities: Background concentrations, distribution, and sources. Chemosphere, 214, 220, 2019.

7. ZHANG J., YANG J., YU F., LIU X., YU Y. Polycyclic aromatic hydrocarbons in urban Greenland soils of Nanjing, China: concentration, distribution, sources, and potential risks. Environmental Geochemistry \& Health, 42 (12), 4327, 2020.

8. WANG C., WU S., ZHOU S.L., WANG H., LI B., CHEN H. YU Y.N., SHI Y.X. Polycyclic aromatic hydrocarbons in soils from urban to rural areas in Nanjing: Concentration, source, spatial distribution, and potential human health risk. Science of the Total Environment, 527-528, 375, 2015.

9. DESALME D., BINET P., CHIAPUSIO G. Challenges in tracing the fate and effects of atmospheric polycyclic aromatic hydrocarbon deposition in vascular plants. Environmental Science \& Technol, 47 (9), 3967, 2013.

10. ZHANG D., WANG J., ZENG H. Soil polycyclic aromatic hydrocarbons across urban density zones in Shenzhen, China: Occurrences, source apportionments, and spatial risk assessment. Pedosphere, 26 (5), 676, 2016.

11. BORTEY-SAM N., IKENAKA Y., NAKAYAMA S.M.M., AKOTO O., YOHANNES Y.B., BAIDOO E., MIZUKAWA H., ISHIZUKA M. Occurrence, distribution, sources and toxic potential of polycyclic aromatic hydrocarbons (PAHs) in surface soils from the Kumasi Metropolis, Ghana. Science of the Total Environment, 496, 471, 2014

12. CACHADA A., PATO P., ROCHA-SANTOS T., FERREIRA DA SILVA E.F., DUARTE A.C. Levels, sources and potential human health risks of organic pollutants in urban soils. Science of Total Environment, 430, 184, 2012

13. YANG Z.P., LU W.X., LONG Y.Q., BAO X.H., YANG Q.C. Assessment of heavy metals contamination in urban topsoil from Changchun city, China. Journal of Geochemical Exploration, 108 (1), 27, 2011.
14. Changchun Statistical Bureau. Bulletin of the seventh national census of Changchun city (No.2). Available online: http://tj.changchun.gov.cn/tjgb/202106/ t20210602 2830522. html (2021)

15. Changchun Statistical Bureau. Changchun Statistical Yearbook. Available online: http:/tjj.changchun.gov.cn/ ztlm/tjnj/202012/t20201204_2615850.html (2020)

16. LI N., WEI X., ZHOU Y.F., SUN S.Y., BAI L. Source analysis and health risk assessment of polycyclic aromatic hydrocarbons in atmospheric environment $\mathrm{PM}_{25}$ in Changchun city. Science Technology \& Engineering, 21 (1), 410, 2021 [In Chinese].

17. WU X., CAO F., ZHAI X.Y., FAN M.Y., ZHANG S.C., ZHANG Y.L. Molecular composition and source apportionment of fine organic aerosols in autumn in Changchun. Environmental Science, 40 (8), 3438, 2019 [In Chinese].

18. ZHANG Y.X., CAO F., ZHENG H., ZHANG D.D., ZHAI X.Y., FAN M.Y., ZHANG Y.L. Source apportionment and health risk assessment of Polycyclic Aromatic Hydrocarbons in PM2.5 in Changchun city, autumn of 2017. Environmental Science, 41 (2), 564, 2020 [In Chinese].

19. LI N., HAN W.Z., TANG J., BIAN J.M., SUN S.Y., SONG T.H. Pollution Characteristics and Human Health Risks of Elements in Road Dust in Changchun, China. International Journal of Environmental Research \& Public Health, 15 (9), 1843, 2018.

20. WANG Z.C., WANG S.Z., NIE J.Q., WANG Y.H., LIU Y.Y. Assessment of polycyclic aromatic hydrocarbons in indoor dust from varying categories of rooms in Changchun city, northeast China. Environmental Geochemistry \& Health, 39 (1), 15, 2017.

21. DAI J.L., LI S.J., ZHANG Y.L., WANG R.Q., YU Y. Distributions, sources and risk assessment of polycyclic aromatic hydrocarbons (PAHs) in topsoil at Ji'nan city, China. Environmental monitoring \& assessment, 147 (1-3), $317,2008$.

22. NGUYEN T.C., LOGANATHAN P., NGUYEN T.V., VIGNESWARAN S., KANDAS AMY J., SLEE D., STEVENSON G., NAIDU R. Polycyclic aromatic hydrocarbons in road-deposited sediments, water sediments, and soils in Sydney, Australia: Comparisons of concentration distribution, sources and potential toxicity. Ecotoxicology \& Environmental Safety, 104, 339, 2014.

23. WEI Q.Z., WANG Y.H., LI S., LUO B., JIA Q., YU J.L., ZHAO H., YUAN X.R., NIU J.P. The source apportionment of PM2.5 based on PCA-MLR model in Lanzhou city. Journal of Environmental Hygiene, 7 (4), 267, 2017 [In Chinese].

24. NEMATOLLAHI M.J., DEHDARAN S., MOORE F., KESHAVARZI B. Potentially toxic elements and polycyclic aromatic hydrocarbons in street dust of Yazd, a central capital city in Iran: contamination level, source identification, and ecological-health risk assessment. Environmental Geochemistry \& Health, 43 (1), 485, 2021.

25. TSAI P.J., SHIH T.S., CHEN H.L., LEE W.J., LAI C.H., LIOU S.H. Assessing and predicting the exposures of polycyclic aromatic hydrocarbons (PAHs) and their carcinogenic potencies from vehicle engine exhaust to highway toll station workers. Atmospheric Environment, 38, 333, 2004.

26. MALISZEWSKA-KORDYBACH B. Polycyclic aromatic hydrocarbons in agricultural soils in Poland: preliminary proposals for criteria to evaluate the level of soil contamination. Applied Geochemistry, 11 (1-2), 121, 1996. 
27. WANG X.T., MIAO Y., ZHANG Y., LI Y.C., WU M.H., YU G. Polycyclic aromatic hydrocarbons (PAHs) in urban soils of the megacity Shanghai: Occurrence, source apportionment and potential human health risk. Science of the Total Environment, 447, 80, 2013.

28. BAO H.Y., HOU S.W., NIU H., TIAN K., LIU X.P., WU F.Y. Status, sources, and risk assessment of polycyclic aromatic hydrocarbons in urban soils of $\mathrm{Xi}^{6}$ an, China. Environmental science \& pollution research, 25 (19), 18947, 2018.

29. MA W.L., LIU L.Y., TIAN C.G., QI H., JIA H.L., SONG W.W. LI Y.F. Polycyclic aromatic hydrocarbons in Chinese surface soil: occurrence and distribution. Environmental science \& pollution research, 22 (6), 4190, 2015.

30. GAO P., DA SILVA E.B., TOWNSEND T., LIU X., MA L.Q. Emerging PAHs in urban soils: Concentrations, bioaccessibility, and spatial distribution. Science of the Total Environment, 670, 800, 2019.

31. SUMAN S., SINHA A., TARAFDAR A. Polycyclic aromatic hydrocarbons (PAHs) concentration levels, pattern, source identification and soil toxicity assessment in urban traffic soil of Dhanbad, India. Science of the Total Environment, 545-546, 353, 2016.

32. DU L.S., WANG Y., WANG J. H., LIU Q., CUI Z.W., LIU J.S. Concentration and distribution of PAHs in vegetables soil in suburb of Changchun city. Environmental Chemistry, 34 (1), 190, 2015 [In Chinese].

33. LIU S.D., XIA X.H., YANG L.Y., SHEN M.H., LIU R.M., Polycyclic aromatic hydrocarbons in urban soils of different land uses in Beijing, China: Distribution, sources and their correlation with the city's urbanization history. Journal of Hazardous Materials, 177 (1-3), 1085, 2010.

34. JIANG Y.F., YVES U.J., SUN H., HU X.F., ZHAN H.Y., WU Y.Q. Distribution, compositional pattern and sources of polycyclic aromatic hydrocarbons in urban soils of an industrial city, Lanzhou, China. Ecotoxicology \& Environmental Safety, 126, 154, 2016.

35. YU G.G., ZHANG Z.H., YANG G.L., ZHENG W.R., XU L.H., CAI Z. Polycyclic aromatic hydrocarbons in urban soils of Hangzhou: status, distribution, sources, and potential risk. Environmental Monitoring \& Assessment, 186 (5), 2775, 2014.

36. ZHAI Y.Z., YIN Z.H., ZHAO X.B., ZHANG J.J., ZUO R., WU J., YANG J., TENG Y.G., WANG J.S. Polycyclic aromatic hydrocarbons (PAHs) in the environment of Beijing, China: Levels, distribution, trends and sources. Human \& Ecological Risk Assessment: An International Journal, 24 (1), 137,2017.

37. SOCLO H.H., GARRIGUES P.H., EWALD M. Origin of polycyclic aromatic hydrocarbons (PAHs) in coastal marine sediments: case studies in Cotonou (Benin) and Aquitaine (France) areas. Marine Pollution Bulletin, 40 (5), 387, 2000.

38. MIZWAR A., PRIATMADI B.J., ABDI C., TRIHADININGRUM Y. Assessment of polycyclic aromatic hydrocarbons (PAHs) contamination in surface soil of coal stockpile sites in South Kalimantan, Indonesia. Environmental monitoring \& assessment, 188 (3), 152, 2016.
39. TOBISZEWSKI M., NAMIESNIK J. PAH diagnostic ratios for the identification of pollution emission sources. Environmental pollution, 162 (1), 110, 2012.

40. YUNKER M.B., MACDONALD R.W., VINGARZAN R., MITCHELL R.H., GOYETTE D., SYLVESTRE S. PAHs in the Fraser river basin: a critical appraisal of PAH ratios as indicators of PAH source and composition. Organic Geochemistry, 33 (4), 489, 2002.

41. HARRISON R.M., SMITH D.J.T., LUHANA L. Source apportionment of atmospheric polycyclic aromatic hydrocarbons collected from an urban location in Birmingham, U.K. Environmental Science \& Technology, 30 (3), 825, 1996.

42. WANG C.Y., ZOU Y.M., YU L.J., LV Y.C. Potential source contributions and risk assessment of PAHs in sediments from the tail-reaches of the Yellow River Estuary, China: PCA model, PMF model, and mean ERM quotient analysis. Environmental Science \& Pollution Research, 27 (9), 9780, 2020.

43. LARSEN R.K., BAKER J.E. Source apportionment of polycyclic aromatic hydrocarbons in the urban atmosphere: a comparison of three methods. Environmental Science \& Technology, 37 (9), 1873, 2003.

44. SIMCIK M.F., EISENREICH S.J., LIOY P.S. Source apportionment and source/sink relationships of PAHs in the coastal atmosphere of Chicago and Lake Michigan. Atmospheric Environment, 33 (30), 5071, 1999.

45. LI J.G., ZHENG Y., LUO X.L., LIN Z.G., ZHANG W., WANG X.J. PAH contamination in Beijing's topsoil: A unique indicator of the megacity's evolving energy consumption and overall environmental quality. Scientific Reports, 6, 33245, 2016.

46. WANG G.D., ZHANG Q., MA P., ROWDEN J., MIELKE H.W., GONZALES C., POWELL E. Sources and distribution of polycyclic aromatic hydrocarbons in urban soils: Case studies of Detroit and New Orleans. Soil \& Sediment Contamination: An International Journal, 17 (6), 547, 2008.

47. YANG J.Y., YU F., YU Y.C., ZHANG J.Y., WANG R.H., SRINIVASULU M., VASENEV V.I. Characterization, source apportionment, and risk assessment of polycyclic aromatic hydrocarbons in urban soil of Nanjing, China. Journal of Soils \& Sediments, 17 (4), 1116, 2016.

48. AMJADIAN K., SACCHI E., \& MEHR M.R. Heavy metals (HMs) and polycyclic aromatic hydrocarbons (PAHs) in soils of different land use in Erbil metropolis, Kurdistan Region, Iraq. Environmental Monitoring \& Assessment, 188 (11), 605, 2016.

49. ZHANG Y., PENG C., GUO Z.H., XIAO X.Y., XIAO R.Y. Polycyclic aromatic hydrocarbons in urban soils of China: Distribution, influencing factors, health risk and regression prediction. Environmental pollution, 254, 112930, 2019.

50. CCME (Canadian Council of Ministers of the Environment). Polycyclic aromatic hydrocarbons. Canadian soil quality guidelines for protection of environmental and human health. Canadian Soil Quality Guidelines, 2010. 


\section{Supplementary Material}

Table S1. Comparison of PAHs concentration with related studies in domestic and foreign cities around the world (ng/g).

\begin{tabular}{|c|c|c|c|c|c|}
\hline \multirow{2}{*}{ Country } & \multirow{2}{*}{ City } & \multirow{2}{*}{ No. of PAHs } & \multicolumn{2}{|c|}{ PAHs (ng/g) } & \multirow{2}{*}{ Reference } \\
\hline & & & Range & Mean & \\
\hline \multirow[t]{2}{*}{ UK } & London & 16 & $4000-66000$ & 18000 & [1] \\
\hline & Glasgow & 15 & $1487-51882$ & 11930 & [2] \\
\hline Iraq & Erbil & 16 & $24.3-6129.1$ & 2296 & [3] \\
\hline India & Dhanbad & 13 & $1019-10856$ & 3488 & [4] \\
\hline Indonesia & Kalimantan & 16 & $4690-22670$ & 11720 & [5] \\
\hline Russia & Moscow & 17 & $4288-8655$ & 5385 & [6] \\
\hline \multirow[t]{2}{*}{ Portugal } & Viseu & 16 & $6.0-790$ & 169 & [7] \\
\hline & Estarreja & 16 & $27-2016$ & 98 & [7] \\
\hline Korea & Ulsan & 16 & $65-12000$ & 960 & [8] \\
\hline Ghana & Kumasi & 22 & $14.8-2084$ & 442 & [9] \\
\hline \multirow[t]{11}{*}{ China } & Hangzhou & 16 & $181-1980$ & 611 & [10] \\
\hline & Shenzhen & 16 & $2-6745$ & 360 & [11] \\
\hline & Nanjing & 16 & $41.2-7016.7$ & 980 & [12] \\
\hline & Xian & 16 & $149.9-5770$ & 1246 & [13] \\
\hline & Dalian & 14 & $219-18727$ & 1104 & [14] \\
\hline & Zhengzhou & 16 & 49.9-11565 & 1567 & {$[15]$} \\
\hline & Urumqi & 16 & $331-15799$ & 5018 & [16] \\
\hline & Lanzhou & 16 & $82.2-10900$ & 2360 & [17] \\
\hline & Shanghai & 16 & $83-7220$ & 1970 & [18] \\
\hline & Beijing & 16 & $8.5-13126.6$ & 1803 & [19] \\
\hline & Changchun & 16 & $46.6-8870.8$ & 1480 & In this study \\
\hline
\end{tabular}




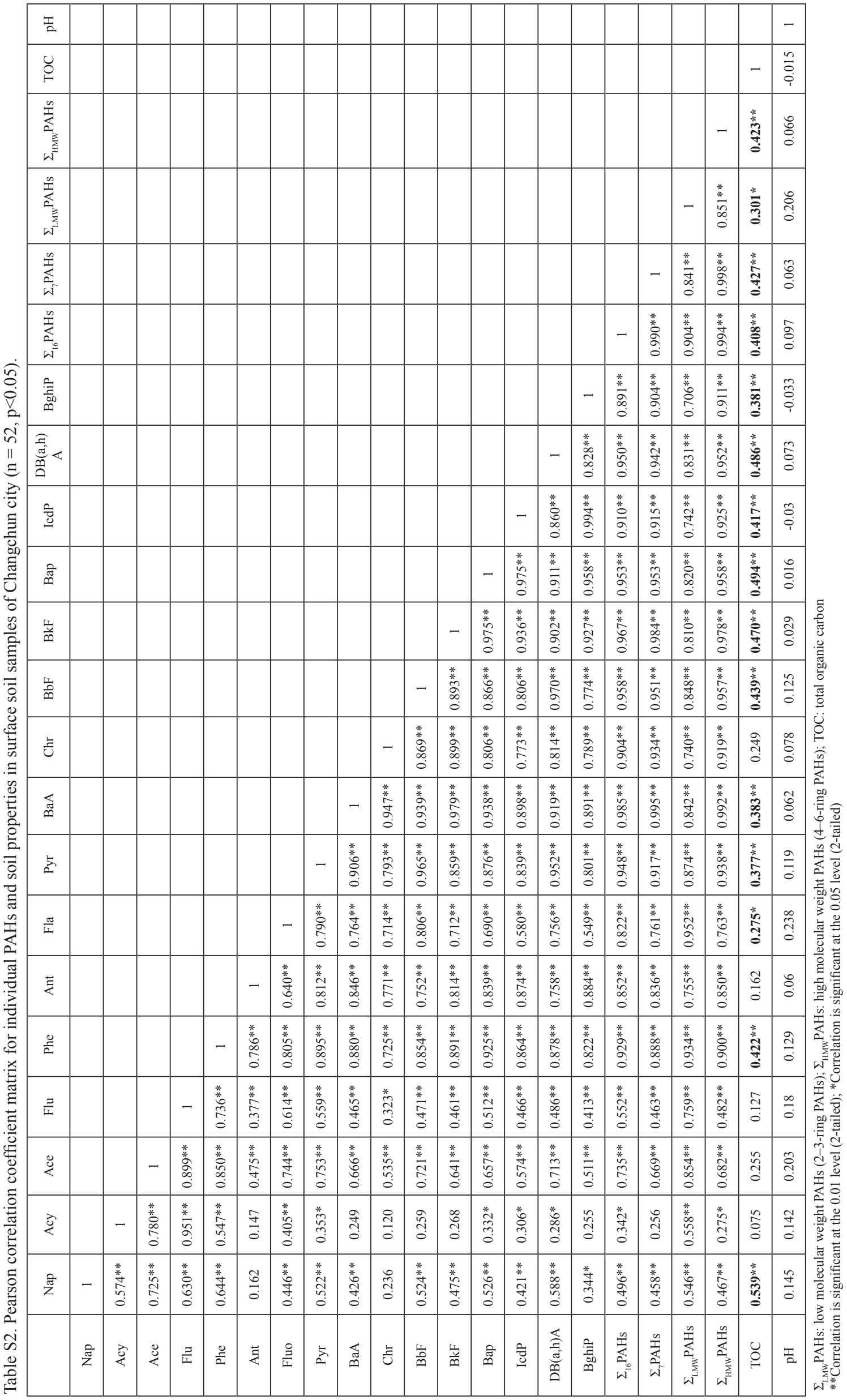




\section{References}

1. VANE C.H., KIM A.W., BERIRO D.J., CAVE M.R., KNIGHTS K., MOSS-HAYES V., NATHANAIL P.C. Polycyclic aromatic hydrocarbons (PAH) and polychlorinated biphenyls (PCB) in urban soils of Greater London, UK. Applied Geochemistry, 51, 303, 2014.

2. MORILLO E., ROMERO A.S., MAQUEDA C., MADRID L.,VILLAVER D.J. Soil pollution by PAHs in urban soils: A comparison of three European cities. Journal of Environmental Monitoring, 9 (9), 1001, 2007.

3. AMJADIAN K., SACCHI E., MEHR M.R. Heavy metals (HMs) and polycyclic aromatic hydrocarbons (PAHs) in soils of different land uses in Erbil metropolis, Kurdistan Region, Iraq. Environmental Monitoring \& Assessment, 188 (11), 605, 2016.

4. SUMAN S., SINHA A., TARAFDAR A. Polycyclic aromatic hydrocarbons (PAHs) concentration levels, pattern, source identification and soil toxicity assessment in urban traffic soil of Dhanbad, India. Science of the Total Environment, 545-546, 353, 2016.

5. MIZWAR A., PRIATMADI B.J., ABDI C., TRIHADININGRUM Y. Assessment of polycyclic aromatic hydrocarbons (PAHs) contamination in surface soil of coal stockpile sites in South Kalimantan, Indonesia. Environmental monitoring \& assessment,188 (3), 152, 2016.

6. NIKIFOROVA E.M., KOSHELEVA N.E. Polycyclic aromatic hydrocarbons in urban soils (Moscow, Eastern District). Eurasian Soil Science, 44 (9), 1018,2011.

7. CACHADA A., PATO P., ROCHA-SANTOS T., DA SILVA E.F., DUARTE A.C. Levels, sources and potential human health risks of organic pollutants in urban soils. Science of the Total Environment, 430, 184, 2012.

8. KWON H.O., CHOI S.D. Polycyclic aromatic hydrocarbons (PAHs) in soils from a multi-industrial city, South Korea. Science of the Total Environment,470-471, 1494, 2014.

9. BORTEY-SAM N., IKENAKA Y., NAKAYAMA S.M.M., AKOTO O., YOHANNES Y.B., BAIDOO E. MIZUKAWA H., ISHIZUKA M. Occurrence, distribution, sources and toxic potential of polycyclic aromatic hydrocarbons (PAHs) in surface soils from the Kumasi Metropolis, Ghana. Science of the Total Environment, 496, 471, 2014

10. YU G., ZHANG Z., YANG G., ZHENG W., XU L., CAI $Z$. Polycyclic aromatic hydrocarbons in urban soils of
Hangzhou: status, distribution, sources, and potential risk. Environmental Monitoring \& Assessment, 186 (5), 2775, 2014.

11. ZHANG D., WANG J., ZENG H. Soil polycyclic aromatic hydrocarbons across urban density zones in Shenzhen, China: Occurrences, source apportionments, and spatial risk assessment. Pedosphere, 26 (5), 676, 2016.

12. YANG J., YU F., YU Y., ZHANG J., WANG R., SRINIVASULU M. VASENEV V.I. Characterization, source apportionment, and risk assessment of polycyclic aromatic hydrocarbons in urban soil of Nanjing, China. Journal of Soils \& Sediments, 17 (4), 1116, 2016.

13. BAO H.Y., HOU S.W., NIU H., TIAN K., LIU X.P., WU F.Y. Status, sources, and risk assessment of polycyclic aromatic hydrocarbons in urban soils of Xi'an, China. Environmental science \& pollution research, 25 (19), 18947, 2018.

14. WANG Z., CHEN J.W., QIAO X.L., YANG P., TIAN F.L.,HUANG L.P. Distribution and sources of polycyclic aromatic hydrocarbons from urban to rural soils: a case study in Dalian, China. Chemosphere, 68 (5), 965, 2007.

15. ZHANG H., WANG J.F., BAO H.Y., LI J., WU F.Y. Polycyclic aromatic hydrocarbons in urban soils of Zhengzhou city, China: occurrence, source and human health evaluation. Bulletin of Environmental Contamination \&Toxicology, 105 (3), 446, 2020.

16. CHEN M., HUANG P., CHEN L. Polycyclic aromatic hydrocarbons in soils from Urumqi, China: distribution, source contributions, and potential health risks. Environmental Monitoring \& Assessment, 185 (7), 5639, 2013.

17. JIANG Y.F., YVES U.J., SUN H., HU X.F., ZHAN H.Y., WU Y.Q. Distribution, compositional pattern and sources of polycyclic aromatic hydrocarbons in urban soils of an industrial city, Lanzhou, China. Ecotoxicology \& Environmental Safety, 126, 154, 2016.

18. WANG X.T., MIAO Y., ZHANG Y., LI Y.C., WU M.H., YU G. Polycyclic aromatic hydrocarbons (PAHs) in urban soils of the megacity Shanghai: occurrence, source apportionment and potential human health risk. Science of the Total Environment, 447 (1), 80, 2013.

19. LIU S.D., XIA X.H.., YANG L.Y., SHEN M.H., LIU R.M. Polycyclic aromatic hydrocarbons in urban soils of different land uses in Beijing, China: distribution, sources and their correlation with the city's urbanization history. Journal of Hazardous Materials, 177 (1-3), 1085, 2010. 